\title{
Indústrias líticas em sítios cerâmicos na Amazônia: um estudo do sítio Domingos, Canaã dos Carajás, Pará.
}

BUENO, L.; PEREIRA, E. Indústrias líticas em sítios cerâmicos na Amazônia: um estudo do sítio Domingos, Canaã dos Carajás, Pará. Revista do Museu de Arqueologia e Etnologia, São Paulo, 17: 99-126, 2007.

Resumo: $\mathrm{O}$ presente artigo apresenta os resultados do estudo do material lítico coletado durante as escavações arqueológicas realizadas no âmbito do "Programa de Arqueologia Preventiva na Área da Mineração Serra do Sossego". A análise do material lítico centrou-se na coleção oriunda das escavações realizadas no sítio Domingos. Essas escavações ocorreram em diferentes momentos, ao longo dos anos de 2003 a 2005. Os objetivos desta análise envolveram a identificação das matérias-primas utilizadas, a caracterização do processo de apropriação de cada uma delas, a definição de indicadores de áreas de atividade através da caracterização dos tipos de modificação produzida nos artefatos da coleção e a distribuição espacial dos vestígios em estratigrafia, de forma a investigar a existência de mais de uma ocupação do sítio Domingos. A partir dos resultados da análise tecnológica e da distribuição dos vestígios líticos intra-sítio, levantamos uma hipótese a respeito do processo de formação deste sítio arqueológico e ressaltamos o potencial de estudos sobre tecnologia lítica em contextos ceramistas.

Palavras-chave: Tecnologia lítica - Tecnologia - Sítio cerâmico - Área de atividade - Processo de formação de sítio.

\section{Introdução}

O presente artigo apresenta os resultados do estudo do material lítico coletado durante as escavações arqueológicas realizadas no âmbito do Programa de Arqueologia Preventiva na Área da Mineração Serra do Sossego, coordenado pela Dra. Edithe Pereira

(*) Museu de História Natural.Universidade Federal de Minas Gerais - UFMG. lucasreisbueno@gmail.com

$\left.{ }^{(* *}\right)$ Museu Paraense Emílio Goeldi. edithe@museu-goeldi.br e financiado pela CVRD, com apoio institucional do MPEG (Pereira 2005).

A análise do material lítico centrou-se na coleção oriunda das escavações realizadas no sítio Domingos, localizado no município de Canaã dos Carajás, PA. Essas escavações ocorreram em diferentes momentos, ao longo dos anos de 2003 a 2005. A partir dos resultados da análise tecnológica e da distribuição dos vestígios líticos intra-sítio, levantamos uma hipótese a respeito do processo de formação deste sítio arqueológico e ressaltamos o potencial de estudos sobre tecnologia lítica em contextos ceramistas. 


\section{Contexto e objetivos}

O sítio mais denso, melhor preservado e escavado com maior intensidade no âmbito do Programa acima mencionado foi o sítio Domingos. Foram realizadas quatro etapas de escavação com duração média de 30 dias entre os anos de 2003 e 2005 (Pereira 2005, 2006a, 2006b, 2006c).

Para delimitação da área de dispersão de vestígios e orientação da localização das unidades a serem escavadas foram utilizados os dados obtidos principalmente através de dois procedimentos: 1) investigação do terreno com material arqueológico por método geofísico através de medidas do campo magnético terrestre, de resistividade aparente e de propagação de onda eletromagnética de freqüência $400 \mathrm{MHz}$, como método de Radar de Penetração no Solo (GPR) (Luiz e Pereira 2005) e; 2) abertura de tradagens em linhas paralelas a cada $10 \mathrm{~m}$, cuja orientação foi definida pelo quadriculamento do sítio com utilização de nível óptico. Os dados obtidos com esses dois procedimentos possibilitaram a definição da área de dispersão de vestígios e uma aproximação da distribuição e densidade de vestígios arqueológicos e terra preta no interior desta área. Essa distribuição orientou então a abertura de unidades de escavação cujo tamanho inicial foi preponderantemente de $1 \mathrm{~m}^{2}$, mas que em muitos casos sofreu ampliações chegando a mais de $20 \mathrm{~m}^{2}$. Em todas as áreas a escavação foi orientada por níveis naturais, definidos de acordo com uma combinação de fatores, como coloração, textura e granulometria do sedimento e tipo, quantidade e distribuição espacial dos vestígios (Pereira 2005).

Com o intuito de verificar a distribuição diferencial dos vestígios materiais no sítio, incluídos aí vestígios líticos, cerâmicos, terra preta e outras estruturas, foram abertas áreas de escavação praticamente em todas as porções do sítio, com o que se obteve uma ótima amostra da diversidade de contextos e do conjunto artefatual presente no sítio.
Em função das características dessa amostragem, os objetivos da análise do material lítico envolveram a identificação das matérias-primas utilizadas, a caracterização do processo de apropriação de cada uma delas, a definição de indicadores de áreas de atividade através da caracterização dos tipos de modificação produzida nos artefatos da coleção e a distribuição espacial dos vestígios em estratigrafia de forma a investigar a existência de mais de uma ocupação do sítio Domingos. Devido à grande quantidade de material coletado, realizamos uma amostragem da coleção, analisando um total de 1225 peças que correspondem a $33 \%$ do total coletado.

\section{Procedimentos Metodológicos}

\section{Metodologia de análise}

Em função do tempo disponível, do tamanho da coleção de material lítico vinculada ao Programa de Arqueologia Preventiva na área da Mineração Serra do Sossego e dos objetivos do trabalho, levantamos duas alternativas metodológicas para realização da análise do material lítico: análise individual dos vestígios (Collins 1975; Andrefsky 1998, 2001; Prentiss 1998; Shott 1994) e análise de massa (Ahler 1989). Apesar de a metodologia relacionada à análise de massa ser mais indicada em função da relação entre o tempo disponível para efetuar a análise e o tamanho da coleção, optamos por realizar uma análise individual dos vestígios com observação de atributos principalmente por dois motivos: 1) não haver um conhecimento prévio sobre o material lítico deste sítio ou de outros sítios associados a ocupações ceramistas nessa região, criando assim a necessidade de se efetuar uma boa caracterização tecnológica dessa indústria; 2) a partir de uma observação preliminar do material lítico do sítio Domingos, identificamos uma grande diversidade de vestígios fazendo com que fosse necessário realizar a observação de atributos para caracterizar melhor os tipos de vestígio presentes. 


\section{A ficha de análise}

Para seleção dos atributos levamos em consideração dois aspectos: informações a serem obtidas e replicabilidade da análise. Este último aspecto teve um papel bastante importante, pois um dos objetivos deste trabalho envolveu a definição de uma metodologia de análise que pudesse ser aplicada nesta e em outras coleções de material lítico por profissionais que contam com pouca experiência na realização de análises de material lítico (Bueno 2006). Nesse sentido, os atributos selecionados e as variáveis a eles relacionadas deveriam ser de fácil identificação.

Foi então elaborada uma ficha de análise a partir da qual todos os vestígios foram classificados. Com isso simplificamos o procedimento de análise, utilizando uma única ficha para todos os tipos de vestígio que, eventualmente, foi complementada com uma descrição mais detalhada, principalmente dos artefatos e núcleos.

Esta ficha é composta por oito atributos, sendo que cada um deles é caracterizado por diferentes variáveis mutuamente excludentes. A ficha pode ser dividida em duas partes: da primeira constam os dados referentes à localização de cada vestígio no sítio - área de escavação, setor e nível; a segunda parte inclui os atributos tecnológicos a serem observados em cada vestígio (ver Tabela 1) (Bueno 2006).

\section{Tabela 1}

\section{I) Matéria-Prima}

$$
\begin{aligned}
& 0 \text { - Não identificada } \\
& 1 \text { - Quartzo } \\
& 2 \text { - Quartzito } \\
& 3 \text { - Granito } \\
& 4 \text { - Basalto } \\
& 5 \text { - Corante } \\
& 6 \text { - Óxido de ferro } \\
& 7 \text { - Laterita } \\
& 8 \text { - outros } \\
& 9 \text { - Arenito } \\
& 10 \text { - Sílex }
\end{aligned}
$$

II) Técnica de transformação

0 - Não identificada

1 - Lascamento Unipolar

2 - Polimento

3 - Bruto/ausente

4 - Lascamento bipolar

5 - Picoteamento

6 - Lascamento/polimento

7 - Lascamento não identificado

8 - Lascamento uni e bipolar

9 - Polimento/Picoteamento

III) Modificação Produzida

0 - Não identificada

1 - Gume

2 - Superfície plana

3 - Depressão

4 - Orifício

5 - Ponta

6 - Queima

7 - Coloração (corante)

8 - Ausente

9 - Superfície plana/depressão

10 - Superfície plana/orifício

11 - Gume/queima

12 - Superfície plana/queima

13 - Orifício/queima

14 - depressão/queima

15 - coloração/queima

16 - outra

17 - estrias

18 - Superfície plana/queima/orifício

19 - polimento geral (no caso de machados, mãos de pilão, etc..)

20 - Picoteamento (percutores)

21 - superfície alisada/gume/queima

22 - superfície alisada/picoteamento

IV) Vestígio produzido

0 - Não identificado

1 - Artefato

2 - Fragmento

3 - Lasca

4 - Núcleo

5 - Bruto

\section{V) Suporte}

0 - Não identificado

1 - Seixo 
2 - Bloco

3 - Fragmento

6 - Nódulo

7 - Cristal

\section{VI) Grau de preservação}

0 - Não identificado

1 - Inteiro

2 - Fragmentado

\section{VII) Grau de transformação}

0 - Não identificado

1 - Total

2 - Parcial

3 - Circunstancial/superficial (restrito)

4 - Ausente

\section{VIII) Dimensões}

0 - Não mensurável

1 - entre 0 e $5 \mathrm{~cm}$

2 - entre 5 e $10 \mathrm{~cm}$

3 - entre 10 e $20 \mathrm{~cm}$

4 - entre 20 e $30 \mathrm{~cm}$

5 - entre 30 e $50 \mathrm{~cm}$

6 - maior que $50 \mathrm{~cm}$

O primeiro atributo diz respeito ao tipo de matéria-prima do vestígio que, de acordo com a amostra analisada até o momento, inclui as seguintes variáveis: quartzo, quartzito, granito, basalto, corante, óxido de ferro, laterita, arenito silicificado, sílex e outros. A variável "outros" inclui uma diversidade de matériasprimas dificilmente distinguíveis sem a utilização de lupas e engloba rochas ígneas e metamórficas localizadas nas proximidades do sítio em diferentes pontos da serra dos Carajás e seu entorno (Brandt/Meio Ambiente 2000).

Algumas dessas rochas foram selecionadas para realização de lâminas petrográficas a fim de definirmos melhor sua composição e relação com atividades específicas realizadas no sítio Domingo.

O segundo atributo observado envolve a identificação da técnica de transformação através da qual o vestígio foi apropriado ao ingressar no sítio arqueológico, indicando se houve uma modificação da matéria-prima antes de sua utilização, ou seja, se para ser utilizada ela sofreu modificações formais ou não. As variáveis associadas a esse atributo são: lascamento unipolar, lascamento bipolar, lascamento não identificado (pode ser uni ou bipolar), lascamento uni e bipolar, polimento, picoteamento, picoteamento/polimento, lascamento/polimento e bruto. A variável "lascamento não identificado" está relacionada aos vestígios de lascamento que não apresentam estigmas claros da utilização de uma ou outra técnica e normalmente são apenas fragmentos. A variável "bruto" é aplicada aos vestígios que não sofreram modificação alguma previamente a sua utilização.

O atributo modificação produzida está relacionado à forma de apropriação produzida pelo tipo de utilização de cada vestígio. As variáveis associadas a esse atributo indicam diferentes tipos de modificação produzidas em cada vestígio em decorrência de ou para sua utilização. A combinação dessas variáveis com aquelas associadas ao atributo técnica de transformação é que vai definir se a modificação identificada foi produzida pela ou para utilização do vestígio, ou seja, previamente ou posteriormente a ela. A partir da amostra estudada foram observadas as seguintes variáveis: gume, superfície alisada, depressão, orifício(s), ponta, queima, alteração de coloração (decorrente do uso de alguma substância, como corante, por ex.), superfície alisada/ depressão, superfície alisada/orifício, gume/ queima, superfície alisada/queima, orifício/ queima, depressão/queima, coloração/ queima, estrias/orifícios, superfície alisada/ orifício/queima, polimento completo, picoteamento, superfície alisada/gume/ queima, superfície alisada/picoteamento, modificação ausente, outras. A variável "estrias/orifício" foi utilizada especificamente para caracterizar as modificações decorrentes da utilização de seixos ou blocos como bigornas no lascamento bipolar enquanto a variável "picoteamento" está associada às modificações decorrentes da utilização do vestígio como percutor, seja para o lascamento unipolar ou bipolar. Já os percutores associados ao processamento de vegetais, ao invés de picoteamento apresentam "orifícios", no caso 
da percussão, ou "superfícies alisadas", no caso da pressão e/ou trituração. A variável "modificação ausente" indica que o vestígio em questão não sofreu modificação alguma referente à sua utilização indicando que ele deve ter sido utilizado em seu estado bruto ou que mesmo tendo sido transformado de alguma maneira (lascado, por exemplo) não sofreu nenhuma modificação associada ao uso (por exemplo, uma lasca que não foi utilizada seria classificada pela variável modificação ausente).

Em seguida passamos à identificação do tipo de vestígio produzido, o qual é decorrente de uma combinação entre a técnica de transformação utilizada e a modificação produzida. As variáveis associadas a esse atributo são as seguintes: artefato, fragmento, lasca, núcleo e vestígio bruto. Classificamos como "artefato" todos os vestígios que sofreram algum tipo de modificação decorrente da realização de uma ação que envolve uma interação entre homem matéria-prima. Assim, com essa classificação só não serão artefatos aqueles vestígios que no atributo modificação produzida forem classificados pela variável "ausente" ou "queima". No primeiro caso fica claro porque o vestígio não pode ser classificado como artefato e no segundo, isso ocorre, pois a modificação produzida não é decorrente de uma interação direta entre homem e matéria-prima, mas sim, de uma reação física decorrente da interação fogo - matéria-prima. Nas variáveis lasca, artefato e núcleo estão englobados, respectivamente, todos os vestígios dessa natureza, independentemente do seu estado de conservação.

Para caracterizar melhor cada vestígio, selecionamos o atributo "suporte" que indica suas características originais, definidas principalmente pelo tipo e pela presença/ ausência de superfície cortical. As variáveis são as seguintes: seixo, bloco, fragmento, nódulo, cristal e não identificada. A última é utilizada, via de regra, quando não há superfície cortical. Já a variável "nódulo" se refere aos seixos rolados em superfície, os quais apresentam superfícies às vezes rugosas e arestas pouco ou mal arredondadas.
$\mathrm{O}$ atributo seguinte indica o grau de preservação de cada vestígio, podendo ele estar inteiro ou fragmentado.

$\mathrm{O}$ atributo grau de transformação indica a intensidade da modificação causada ao vestígio através da sua utilização e fornece uma medida importante da transformação formal pela qual cada suporte passou ao ser apropriado no conjunto das atividades desenvolvidas no sítio. Nesse sentido, o grau de transformação pode estar ausente, ser apenas circunstancial/ superficial, ser parcial ou total.

Por fim, o último atributo a ser analisado envolve a dimensão de cada vestígio, calculada por intervalos.

\section{Amostragem}

Já para a amostragem, optamos por realizar uma análise inicial de todo o material lítico coletado durante a etapa de campo realizada em agosto de 2005 uma vez que essa coleção cobria o maior número de áreas localizadas em diferentes setores do sítio e já havíamos tido um primeiro contato com esse material, em função da participação na referida etapa de campo.

Posteriormente, a partir dos resultados obtidos realizamos uma amostragem baseada em três critérios: 1) localização da área de escavação no sítio, de modo a privilegiar áreas ainda pouco representadas na amostra já analisada; 2) densidade de vestígios por área de escavação; 3) quantidade de vestígios na camada 2 . Com a combinação destes critérios e do tempo disponível, selecionamos, em ordem de prioridade, as seguintes áreas de escavação para serem analisadas: 37, 31, 24 e 25.

Através da utilização dessa metodologia procuramos responder basicamente seis questões, todas derivadas de duas questões principais: 1) Por que e para que há material lítico neste sítio? 2) Como esse material lítico foi apropriado?

Para responder a essas questões, outras foram então formuladas:

- Quais foram as matérias-primas utilizadas? - Onde elas foram obtidas? 
- Para qual finalidade cada uma delas foi utilizada?

- Como cada uma delas foi transformada e utilizada e qual a relação entre matérias-primas, técnica de transformação e forma de utilização? - Em quais locais do sítio elas foram utilizadas? - Como se dá a distribuição das variáveis de cada atributo observado na estratigrafia?

\section{A indústria lítica do sítio Domingos}

\section{Matérias-primas e especificidades de aproveitamento}

As matérias-primas podem ser divididas em dois grandes grupos em termos de composição, estrutura, fonte e formas de apropriação: quartzo e quartzito $\mathrm{X}$ granito e outros tipos de rocha ígnea ou metamórfica. Além destas, são freqüentes também fragmentos de laterita, placas de óxido de ferro, corantes e, em escala bastante reduzida, basalto, arenito silicificado e sílex.

Quartzo e quartzito aparecem preferencialmente na forma de seixos, mas podem também ocorrer como nódulos ou, no caso do quartzo na forma de cristal que, nesse caso, apresenta um quartzo hialino. Na maioria das vezes o quartzo é leitoso ou fosco, mas em geral de má qualidade com muitas fraturas internas que dificultam o controle dos vestígios produzidos através do lascamento. Assim como o quartzo, o quartzito é em geral de má qualidade e apresenta bastante variação quanto à textura, o grau de coesão entre os grãos e a intensidade de transformação em função do metamorfismo. Principalmente os nódulos são de péssima qualidade, muito friáveis e particularmente ruins para o lascamento. No entanto, apesar dessas restrições quanto à aptidão ao lascamento, na amostra analisada o quartzo é a matériaprima melhor representada e o quartzito a terceira. Isso, por sua vez, não implica que o lascamento seja a técnica de transformação predominante no sítio, pois, muitos vestígios dessas e das demais matérias-primas presentes no sítio Domingos foram apropriados em estado bruto.

No caso do quartzo, a maioria dos vestígios identificados no sítio foi efetivamente apropriada através do lascamento, principalmente unipolar. Não houve, nessa matériaprima, nenhum tipo de transformação associada a polimento ou picoteamento e a maioria dos artefatos caracterizados pela formação de gumes foi confeccionada em quartzo.

Já o quartzito, foi majoritariamente apropriado na forma bruta, seguida pela técnica de lascamento, em particular a bipolar. Esse tipo de apropriação dessa matéria-prima está melhor representado na camada 2 do sítio, como discutiremos adiante, e aparece concentrado numa pequena área composta por inúmeros seixos superficialmente lascados, muitos sem gerar uma única lasca, associados a outros seixos que apresentam marcas de picoteamento ou de estrias, o que interpretamos como o refugo do processo de lascamento bipolar, com núcleos, percutores e bigornas descartados (Figs. 1 e 2).

Ainda com relação à matéria-prima, dentre os vestígios classificados com o atributo outros, se insere uma grande variedade de matériasprimas que, como já frisamos, são difíceis de distinguir a olho nu. Esse conjunto aparece em segundo lugar como a matéria-prima melhor representada no sítio. Todas elas apresentam características comuns quanto a sua forma de apropriação. A maioria delas foi utilizada bruta, apresenta sinais intensos resultantes da exposição à ação térmica e se encontram na forma de fragmentos oriundos de blocos.

Dentre esse conjunto de matérias-primas há algumas que se destacam em função da sua composição e estrutura, como é o caso, por exemplo, de um tipo composto por grandes minerais de quartzo angulosos, como se fosse um grande bloco de areia mal consolidado em meio a uma rocha ígnea. Especificamente esse tipo de matéria-prima aparece bastante modificada por ação térmica, em fragmentos de diversos tamanhos e, em um local específico do sítio, associada a um batedor produzido sobre seixo de quartzito. Uma pergunta que se coloca e que pode ser resolvida por análises físico-químicas diz respeito a uma possível utilização dessa rocha fragmentada como antiplástico para a cerâmica produzida no sítio. Neste caso, o processo de produção do 


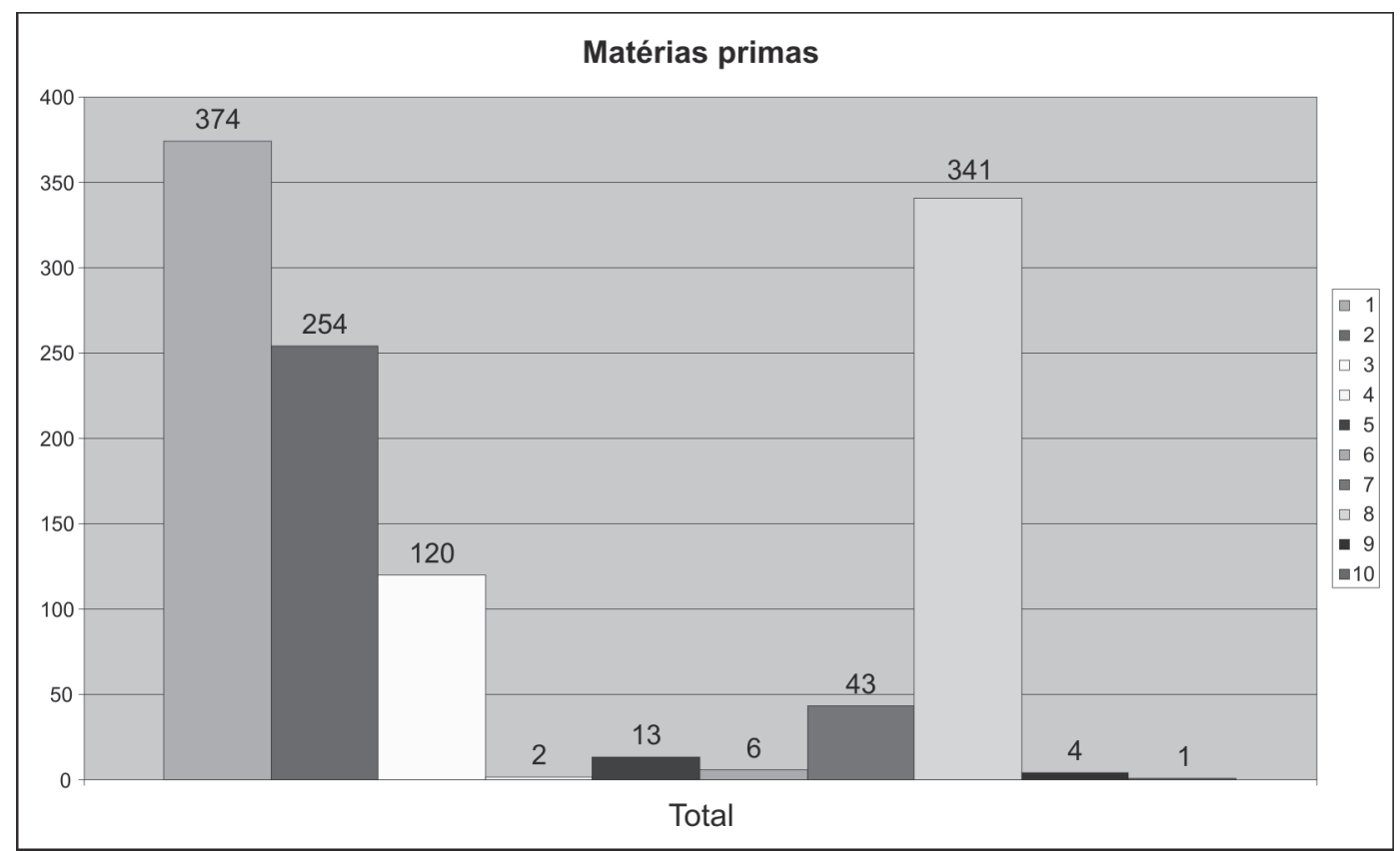

Fig. 1. Gráfico de distribuição das matérias-primas no sítio Domingos.

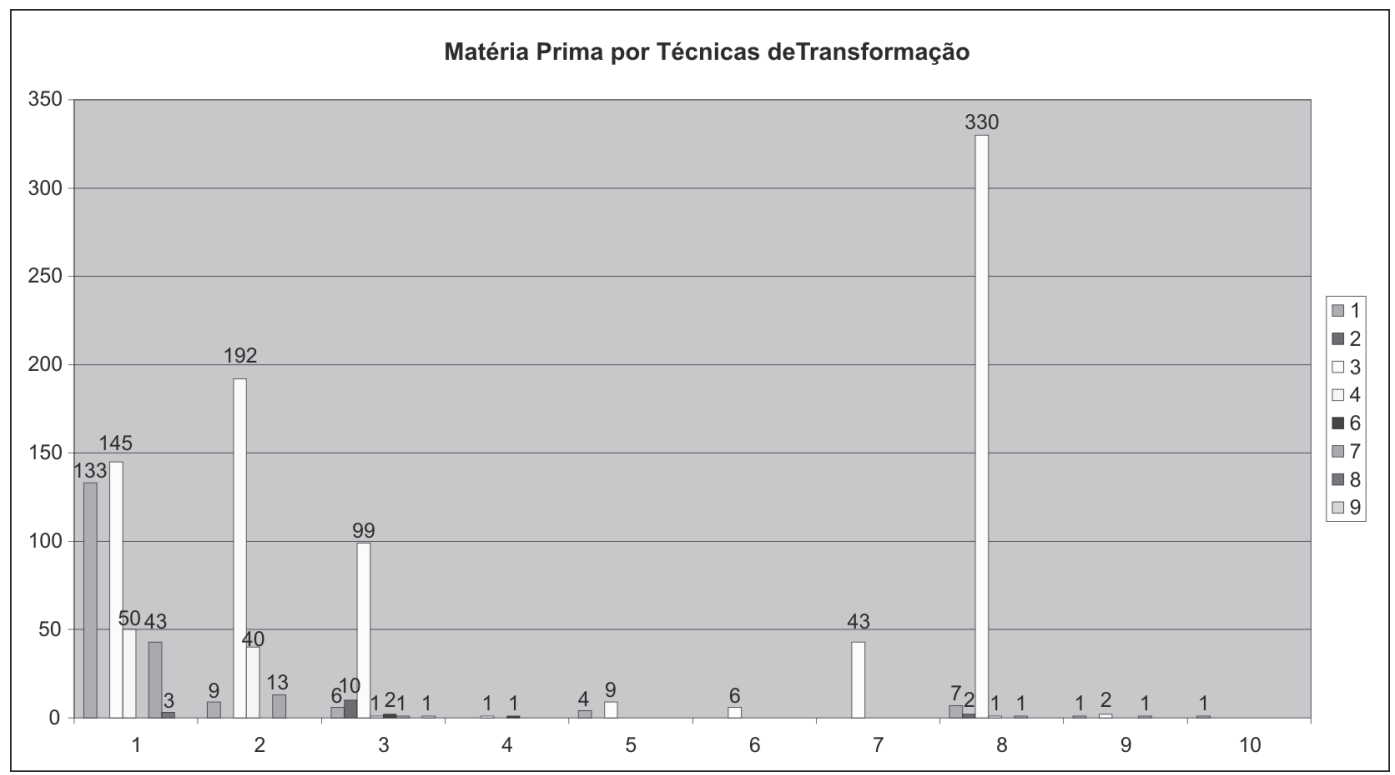

Fig. 2. Gráfico da relação entre matéria-prima e técnica de transformação no sítio Domingos.

antiplástico envolveria uma primeira etapa na qual grandes blocos dessa matéria-prima seriam fragmentados pela ação do fogo até gerarem pequenos fragmentos que seriam então macerados com a utilização de um percutor duro. Análises preliminares realizadas com a cerâmica indicam a predominância de antiplástico mineral, principalmente grãos de quartzo e fragmentos de laterita, indicando que a hipótese apresentada é bastante plausível. 
O granito presente no sítio Domingos aparece em fragmentos derivados de blocos e está associado, na maioria das vezes, a uma utilização circunstancial que produz superfícies alisadas planas. No entanto, dentre os poucos machados polidos encontrados nesta coleção, a maioria foi confeccionada também em granito. Tanto os fragmentos que apresentam essas marcas de utilização circunstancial quanto aqueles que permanecem em estado bruto apresentam, via de regra, sinais de queima. Alguns fragmentos foram produzidos por lascamento unipolar e, na área de escavação 37, nível 1C, encontramos um grande fragmento intensamente lascado pela técnica bipolar que pode representar o vestígio de uma etapa de produção de artefatos polidos, como os machados, por exemplo.

As outras matérias-primas presentes na coleção, como corante, laterita e as placas de óxido de ferro aparecem em pequena quantidade. Destas a laterita é a melhor representada. Normalmente ela aparece em fragmentos brutos que não parecem ter sofrido alteração alguma a não ser uma fragmentação decorrente do uso do fogo. Já os corantes e o óxido de ferro, são também apropriados brutos, mas apresentam sinais de utilização, com a presença de estrias nos corantes e superfícies alisadas e mudança de coloração no óxido de ferro.

\section{As técnicas de apropriação}

A maior parte do material lítico até o momento analisado ingressou no sítio e foi utilizado no estado bruto, ou seja, sem passar por qualquer tipo de modificação prévia. Dentre estes, a maioria esteve associada à utilização do fogo, seja em fogueiras associadas ao processamento de alimentos, à produção cerâmica ou em outras atividades nas quais o fogo seria o principal agente. Como mencionamos anteriormente, uma outra utilização do fogo associada a determinados tipos de matéria-prima poderia envolver a fragmentação intencional de grandes blocos com o intuito de obter pequenos fragmentos que seriam posteriormente macerados com o uso de percutor duro a fim de gerar pequenos grãos de diferentes minerais, mas principalmente quartzo, utilizados como antiplástico na produção cerâmica (Fig. 3).

Além do material utilizado ou apropriado de forma bruta, identificamos a presença de vestígios transformados através da utilização das

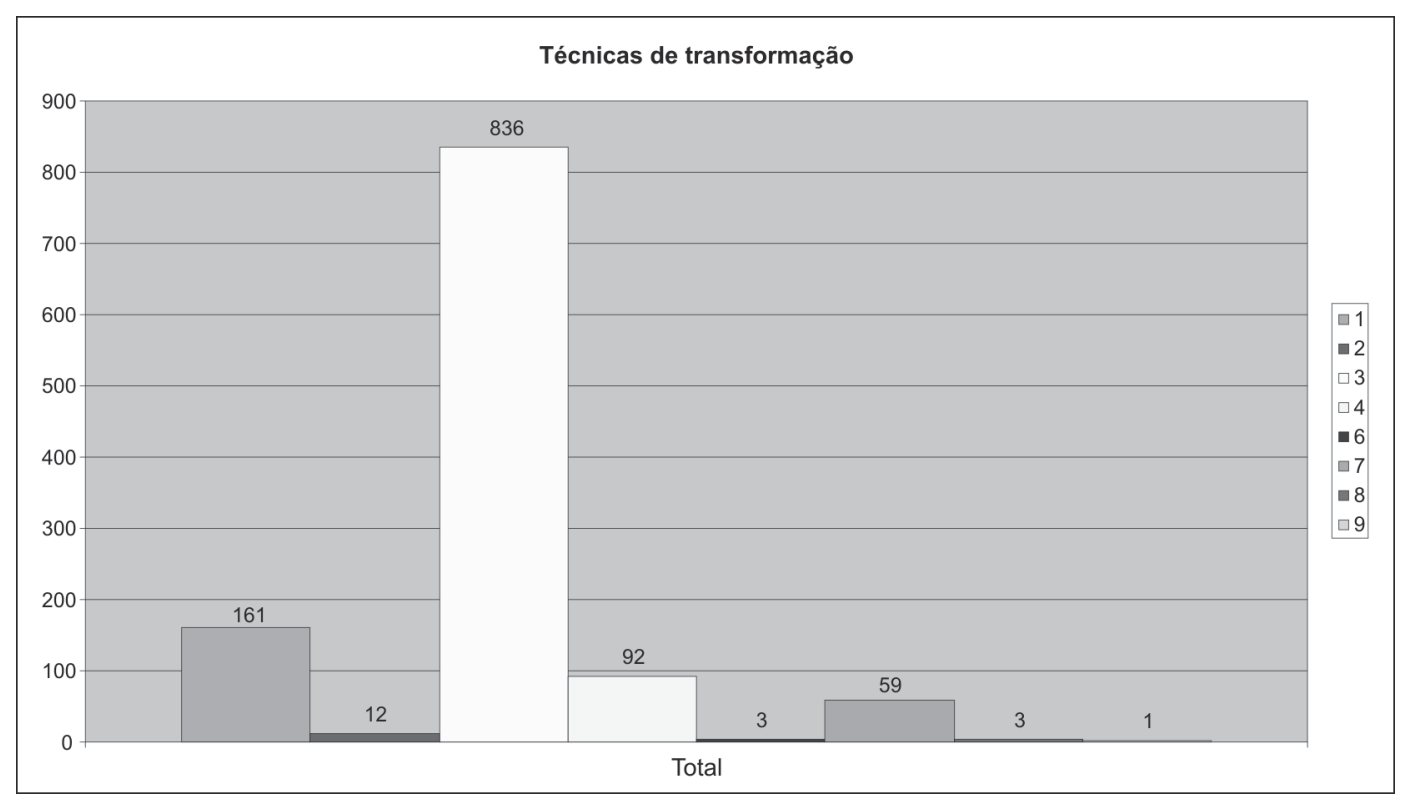

Fig. 3. Gráfico da distribuição das técnicas de transformação no sítio Domingos. 
técnicas de lascamento unipolar, lascamento bipolar, polimento, picoteamento ou, em alguns casos, uma combinação destes.

Esses últimos, apesar de quantitativamente insignificantes, apontam aspectos bastante interessantes, como por exemplo, a presença de núcleos lascados através de uma combinação entre técnica unipolar e bipolar, a produção de artefatos conjugando etapas de lascamento e polimento. Neste caso, em específico, há um vestígio bastante interessante, de granito lascado pela técnica bipolar e superficialmente polido que pode representar uma etapa inicial da produção de um machado polido, indicando aí a presença de uma cadeia operatória bastante particular e, portanto importante no estabelecimento de comparações com demais sítios da região.

\section{As modificações produzidas e os vestígios gerados}

Conforme mencionado anteriormente, a grande maioria dos vestígios que sofreu algum tipo de modificação decorrente do seu processo de apropriação esteve relacionada ao uso do fogo. São vestígios que ingressaram no sítio em seu estado bruto e não sofreram nenhum tipo de modificação prévia a sua utilização. Nesses vestígios, as únicas modificações identificadas são decorrentes da sua associação a atividades que envolveram o uso do fogo e que, em decorrência de uma ação térmica, produziram uma grande quantidade de fragmentos. Em alguns casos, no entanto, a baixa intensidade da ação térmica à qual esses blocos foram submetidos fez com eles permanecessem inteiros, em seu estado bruto, com apenas alguns sinais de queima.

A segunda variável melhor representada neste atributo está relacionada aos vestígios que não sofreram modificação alguma, sendo apropriados e utilizados no sítio em seu estado bruto. Dentre esses vestígios, muitos podem ter sido efetivamente utilizados na realização de uma atividade que envolve a interação direta homem-matéria-prima, mas que foi muito efêmera para produzir qualquer tipo de modificação ou que realmente não envolve nenhum tipo de modificação.
Em seguida, aparecem melhor representadas as variáveis que indicam a presença de modificações caracterizadas pela formação de marcas de picoteamento e estrias. Na coleção analisada essas modificações estão associadas à utilização de seixos no processo de lascamento bipolar e representam, respectivamente, percutores e bigornas. A grande quantidade desse tipo de vestígio, no entanto, não reflete a distribuição das técnicas de transformação das matériasprimas de uma maneira geral no sítio, pois estão, em sua grande maioria, associadas a uma única estrutura identificada na área de escavação 37, nível 2, composta essencialmente por seixos de quartzito (Fig. 4).

Já as modificações produzidas pela formação de gumes nos vestígios analisados aparecem em quarto lugar e estão representadas pelas variáveis 1 - gume - e 11 - gume e queima. Essas modificações envolvem a produção de gumes com diferentes extensões, formas e ângulos e estão associadas na maioria das vezes aos vestígios transformados pela utilização da técnica de lascamento, seja ele uni ou bipolar. Esse tipo de modificação está, via de regra, associado à realização de atividades que envolvem ações como raspar e cortar. Os artefatos que apresentam esse tipo de modificação foram confeccionados majoritariamente em quartzo, mas há alguns também em quartzito e poucos nas demais matérias-primas. Outra característica desses artefatos é que as modificações decorrentes de sua utilização são sempre circunstanciais indicando uma utilização expediente associada à realização de uma necessidade imediata seguida pelo descarte do artefato.

Outro tipo de modificação produzida bastante recorrente nesta coleção envolveu a produção de superfícies alisadas. Essas superfícies foram identificadas em diversos blocos de granito ou em outras matérias-primas ígneas e metamórficas, normalmente oriundas de blocos. Elas atingem diferentes extensões do bloco e produzem sempre superfícies planas que podem ser horizontais ou inclinadas. Em alguns casos essas superfícies são produzidas em duas faces do bloco gerando superfícies planas paralelas. A maioria dos artefatos que apresenta essas modificações se encontra fragmentada em decorrência 


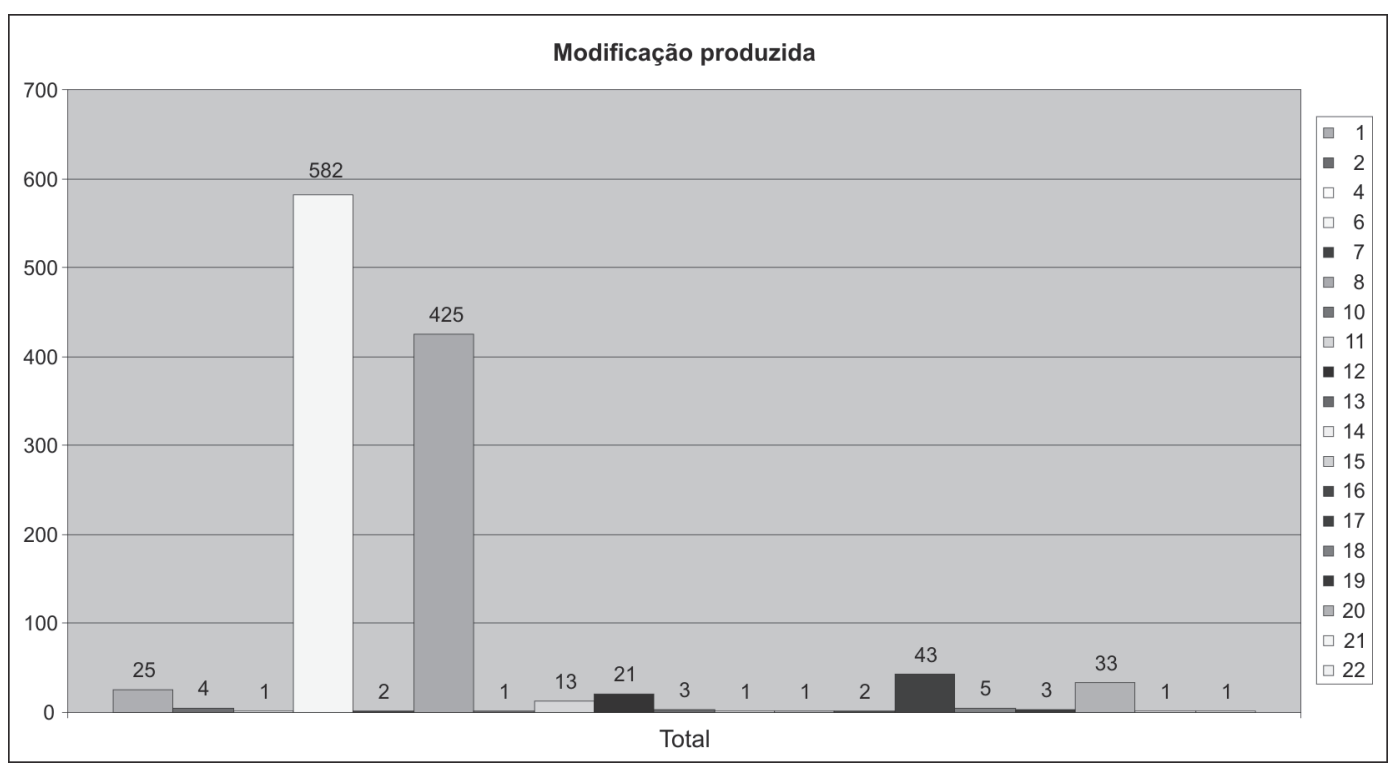

Fig. 4. Gráfico das modificações produzidas no sítio Domingos.

de ação térmica que corta justamente a parte polida do bloco. Em função da superficialidade da modificação produzida, de sua localização no bloco e com base em referências bibliográficas a interpretamos como decorrência do uso associado ao processamento de material vegetal. Ou seja, essa modificação não teria sido produzida previamente a utilização do bloco, mas sim em decorrência desta utilização. No gráfico 4 há uma série de variáveis que indicam a presença desse tipo de modificação que aparecem separadas em função da sua associação com outros tipos de modificação. Esse é o caso, por exemplo, da variável identificada pelo número 10 - superfície alisada e orifício, 12 - superfície alisada com marcas de queima, 18 - superfície alisada, orifício e queima e 22 - superfície alisada e picoteamento.

Identificamos ainda outros tipos de modificação em alguns vestígios de diferentes matériasprimas produzidos pela utilização de vestígios brutos que envolvem sinais de picoteamento, estrias, orifícios, depressão e às vezes uma combinação delas. Todas essas modificações apontam para a realização de atividades que envolvem ações como amassar, triturar, pilar, percutir e esmagar.
Diferentemente dos vestígios cuja modificação envolve a produção de um gume, aqueles associados a modificações relacionadas com atividades que envolvem as ações acima citadas apresentam marcas de queima bastante intensas, apontando assim para uma possível associação entre esse tipo de atividade e áreas nas quais a utilização do fogo é intensa e recorrente (Fig. 5).

A partir da caracterização dos procedimentos envolvidos na apropriação de cada uma das diferentes matérias-primas utilizadas no sítio Domingos e das técnicas de transformação associadas à utilização dos vestígios líticos (Bueno 2006), pudemos identificar tanto indicadores de áreas de atividades diferenciadas em uma das camadas de ocupação do sítio (camada 1c), como indicadores de indústrias líticas distintas associadas a diferentes camadas de ocupação do sítio (camadas 1C e 2).

Distribuição do material lítico em estratigrafia e os indicadores de diferentes ocupações

Feita essa caracterização geral das matériasprimas identificadas no sítio, das técnicas de apropriação, modificação produzida e dos vestígios gerados, podemos analisar a distribui- 


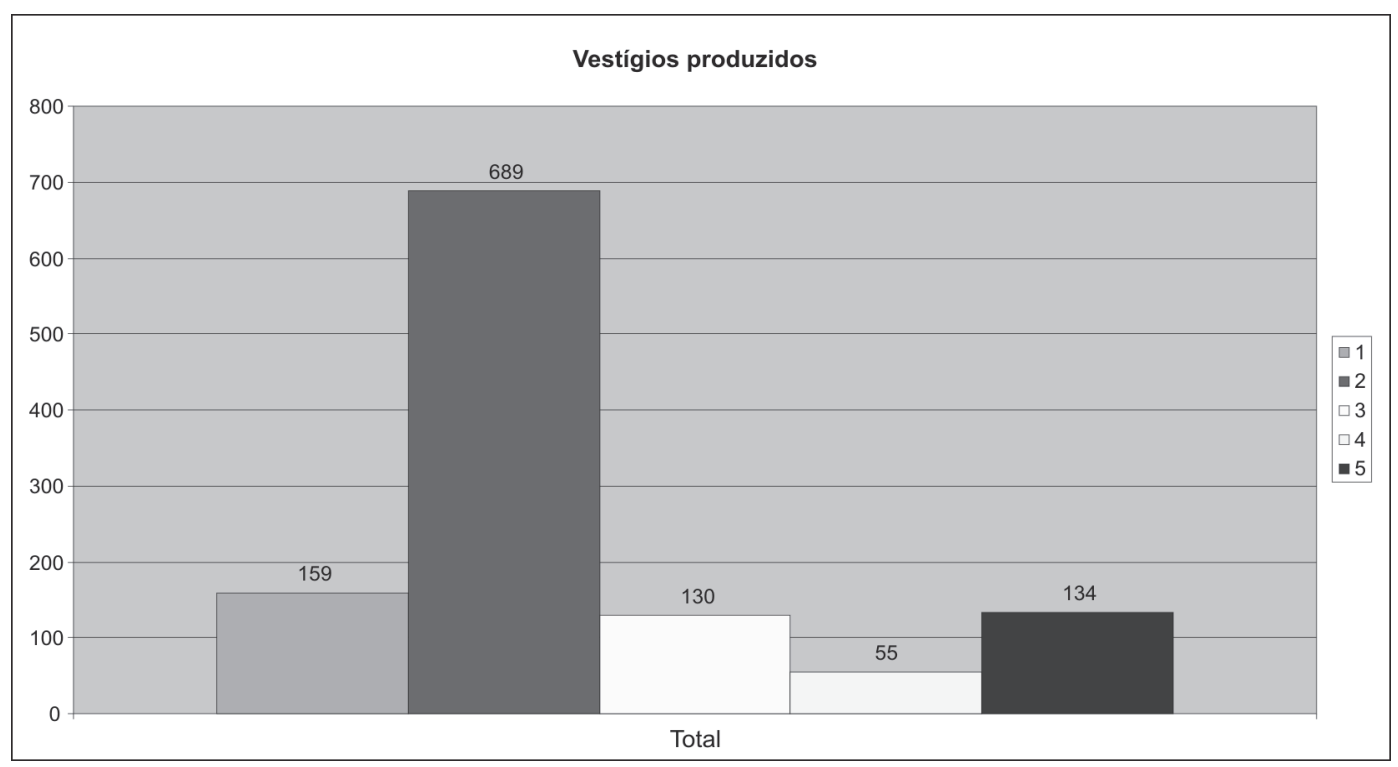

Fig. 5. Gráfico de vestígios produzidos no sítio Domingos.

ção estratigráfica dos vestígios no sítio a fim de procurar averiguar a existência de diferentes camadas de ocupação.

Um primeiro aspecto que pode ser observado diz respeito à distribuição total de vestígios líticos por níveis de escavação. Conforme observamos na Tabela 2, esse tipo de vestígio se concentra na camada $1 \mathrm{C}$, seguida pela 2 e pela $1 \mathrm{D}$, sendo $1 \mathrm{~A}$ e $1 \mathrm{~B}$ muito pouco representadas. A partir dessa distribuição podemos levantar duas possibilidades: o nível $1 \mathrm{C}$ representa a camada de ocupação associada à ocupação mais intensa do sítio e o fato de haver uma diminuição drástica da quantidade de vestígios da camada $1 C$ para a camada $1 \mathrm{D}$, seguida de um aumento na camada 2 pode indicar que esta última representaria um segundo momento de ocupação mais intensa. Ou seja, a camada 2 poderia representar o primeiro evento de ocupação do sítio, seguido de uma diminuição na intensidade da ocupação no que se refere à camada $1 \mathrm{D}$ e, posteriormente, uma ocupação mais intensa representada pela camada $1 \mathrm{C}$ e depois pelo abandono do sítio. Para averiguar essa hipótese é preciso investigar a distribuição dos tipos de vestígio, o que faremos exclusivamente para os níveis $1 \mathrm{C}$ e 2 .
Tabela 2

Quantidade de vestígio por níveis estratigráficos no sítio Domingos

\begin{tabular}{lc}
\hline Níveis & Quantidade de vestígios \\
\hline \hline 1A & 18 \\
1B & 132 \\
1C & 1811 \\
1D & 351 \\
2 & 664 \\
\hline
\end{tabular}

No que tange à distribuição das matériasprimas podemos ver uma diferença significativa entre os níveis 2 e $1 \mathrm{C}$ (Figs. 6a e 6b). No nível 2 predomina o quartzito, seguido pelo quartzo, representando os dois juntos $82 \%$ do total de vestígios líticos desse nível, enquanto o granito e outros representam apenas 14\%. Já no nível $1 \mathrm{C}$, a matéria-prima mais representada inclui o conjunto de matérias-primas designadas pela variável outros, seguida pelo quartzo, pelo granito e só então pelo quartzito. Nesse nível a variável outros, junto com granito representam 54\% do total dos vestígios enquanto quartzo e quartzito apenas 39\%. Outra diferença entre esses dois níveis diz respeito à presença de corante e placas de 
óxido de ferro exclusivamente no nível $1 \mathrm{C}$ e à maior representatividade de fragmentos de laterita também neste nível.

Ao contrário do que ocorre com as matérias-primas, a distribuição das técnicas de apropriação não apresenta diferenças tão significativas entre os níveis $1 \mathrm{C}$ e 2 (Figuras 7 a e $7 \mathrm{~b}$ ). Em ambos predominam os vestígios apropriados de forma bruta (76 e $64 \%$ respectivamente). Em seguida a técnica de apropriação mais representada é o lascamento que, no nível 1C, envolve o lascamento unipolar e no nível 2 o lascamento bipolar. Vestígios nos quais identificamos a utilização combinada entre lascamento e polimento e lascamento uni e bipolar aparecem nos dois níveis e em ambos com baixa representatividade.

Quanto às modificações produzidas, há uma inversão entre os níveis $1 \mathrm{C}$ e 2 e há no nível 1C uma variedade de tipos de modificação produzida bastante superior àquela identificada na camada 2 , indicando assim a realização de um número maior de diferentes

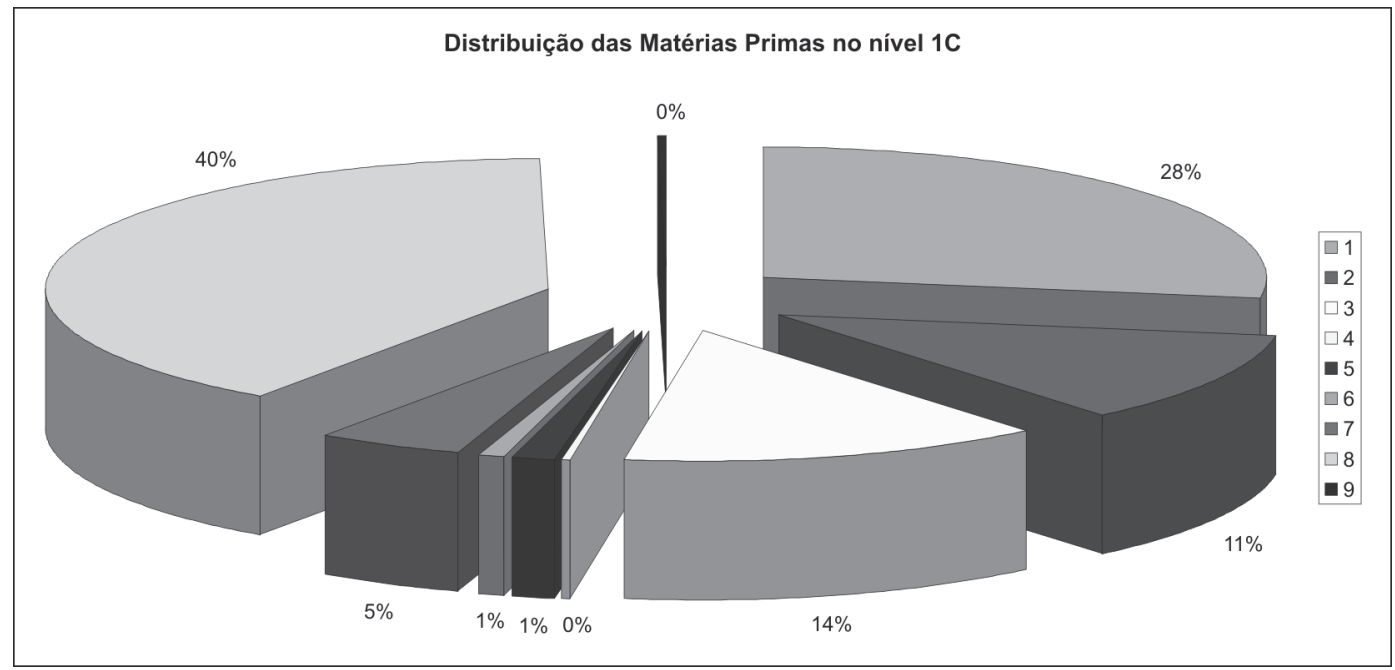

Fig. 6a. Gráfico da distribuição das matérias-primas no nível 1C do sítio Domingos.

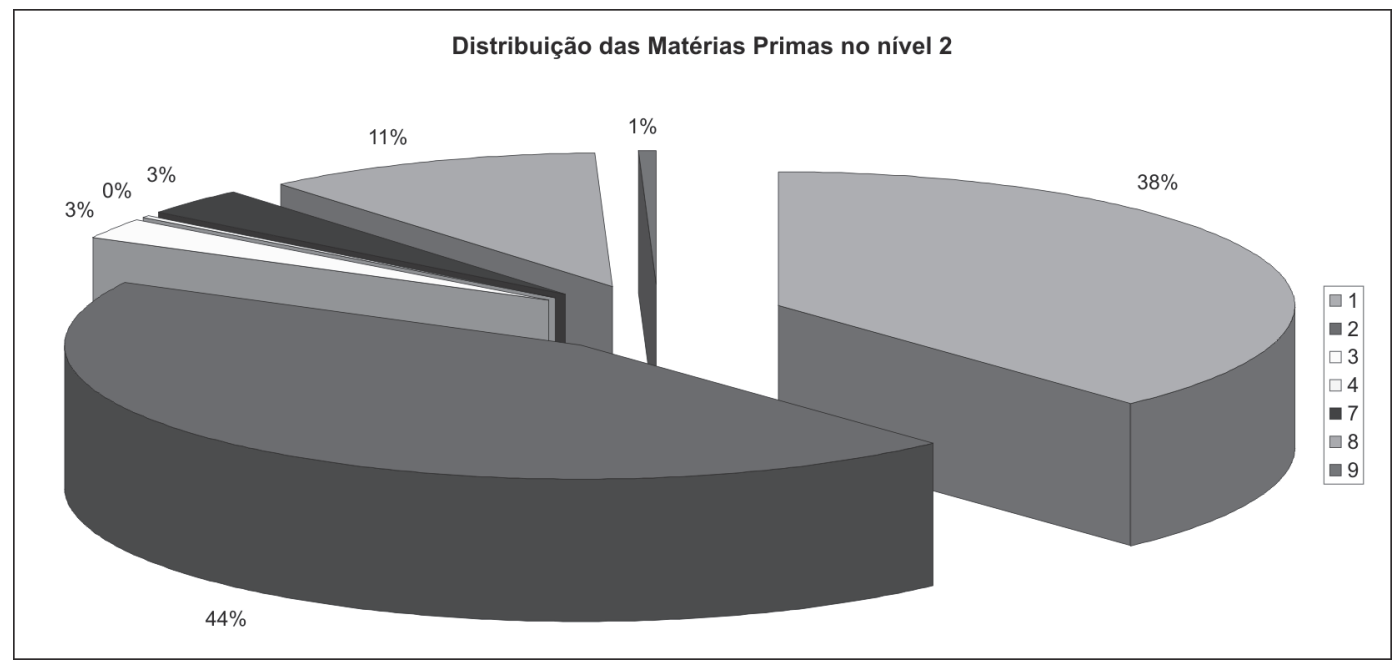

Fig. 6b. Gráfico da distribuição das matérias-primas no nível 2 do sítio Domingos. 


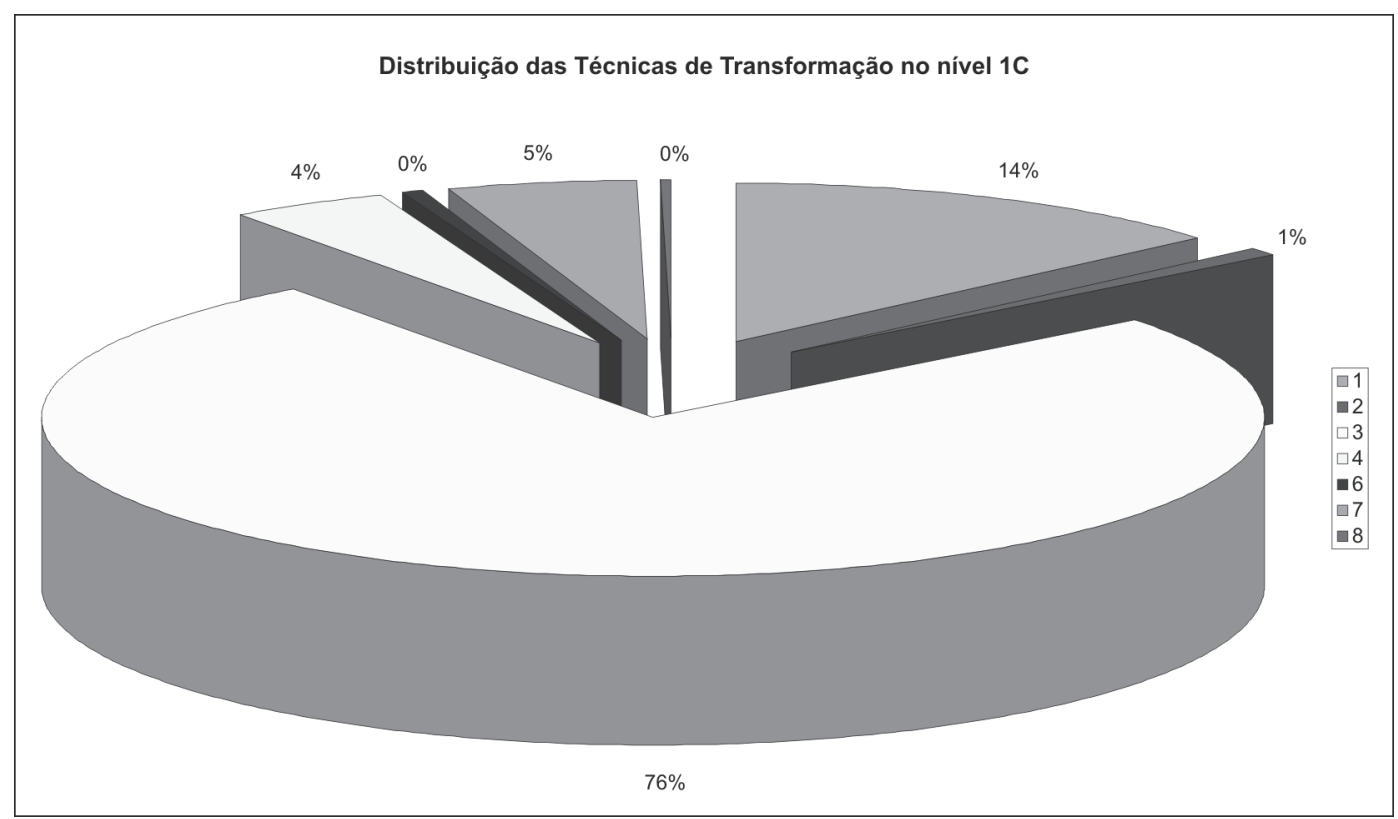

Fig. 7a. Gráfico da distribuição das técnicas de transformação no nível 1C do sítio Domingos.

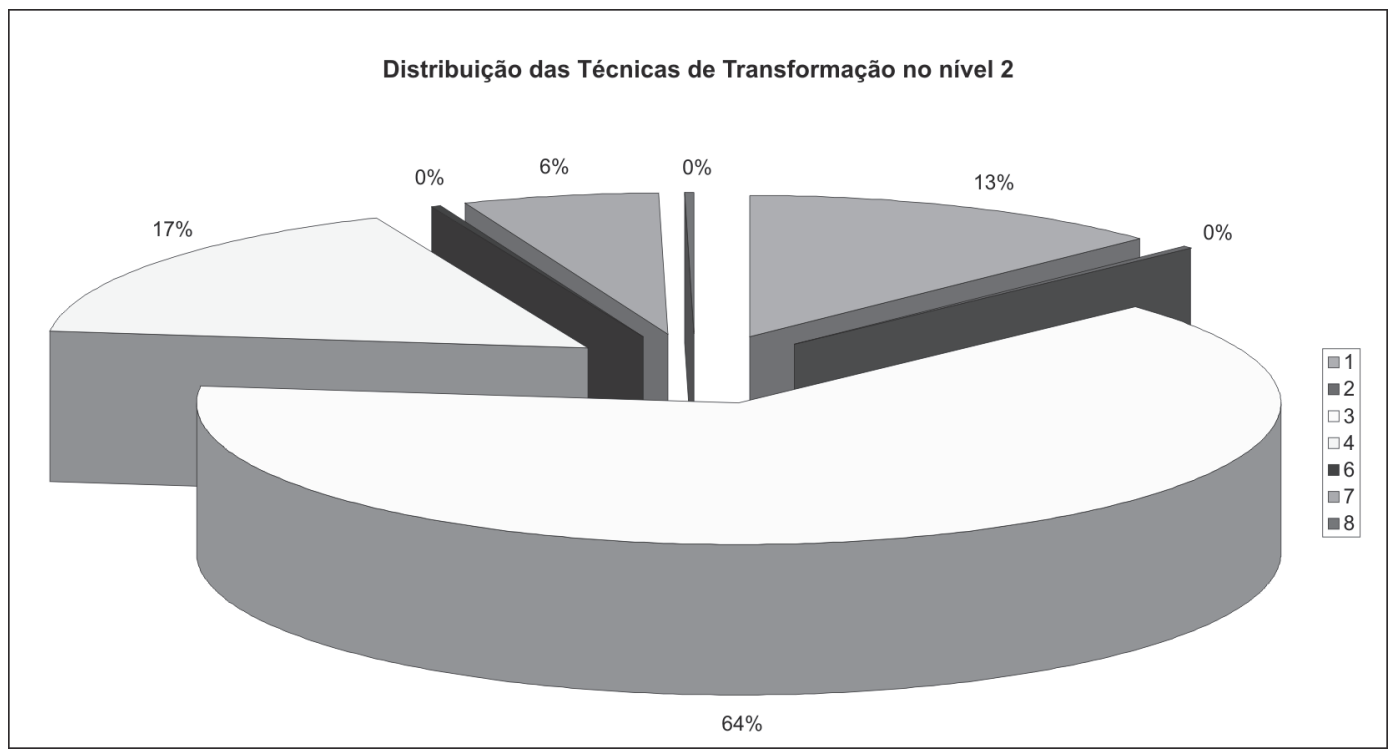

Fig. 7b. Gráfico da distribuição das técnicas de transformação no nível 2 do sítio Domingos.

formas de utilização das matérias-primas líticas (Figs. 8a e 8b).

No nível 1C predominam as modificações causadas pela ação do fogo, identificadas em $61 \%$ dos vestígios. Em seguida aparecem os vestígios com modificação ausente, com 31\% e a partir daí uma série de outras modificações com baixa representatividade que incluem, por exemplo, a produção de superfícies alisadas, de gumes, de superfície planas com orifícios, de picoteamento, polimento, depressão e alterações de coloração. Se agruparmos os tipos de modificação em função do tipo de ação relacionada a sua produção, teríamos uma polarização 


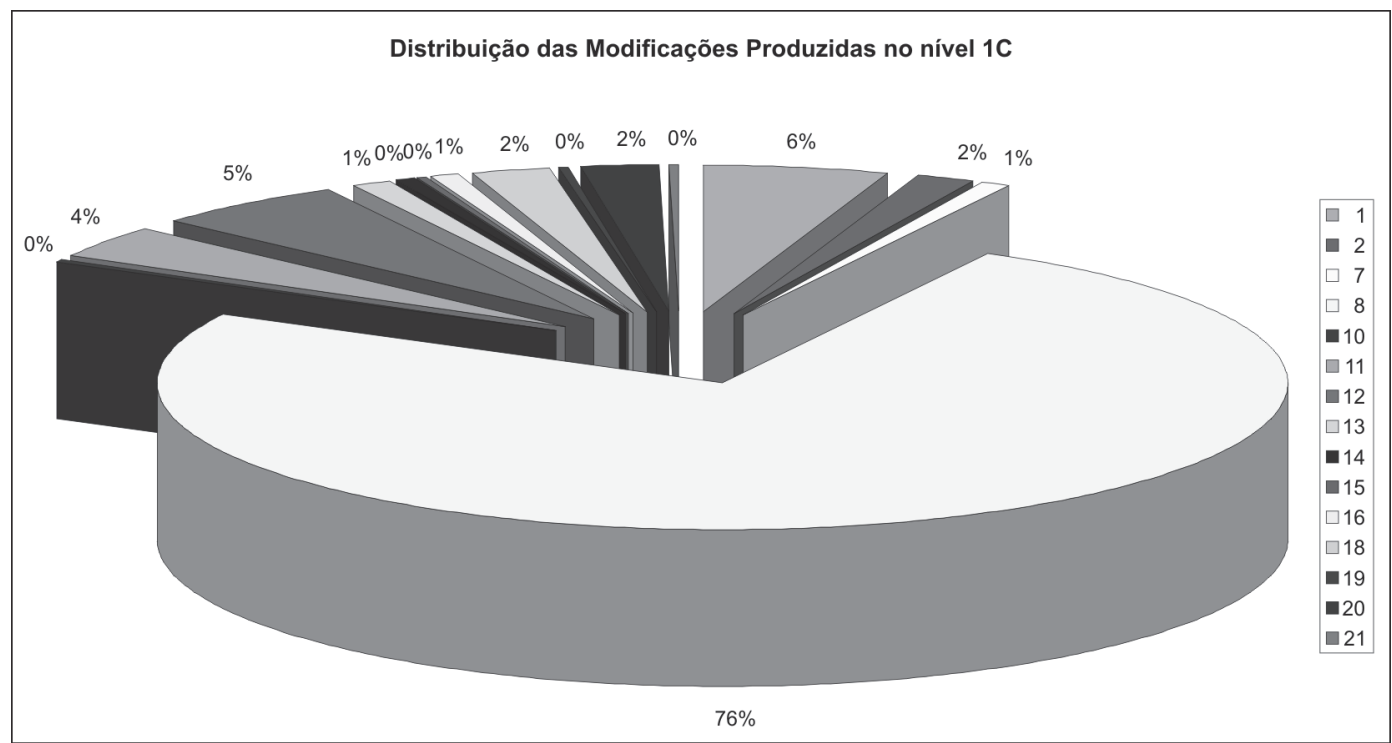

Fig. 8a. Gráfico da distribuição das modificações produzidas no nível 1C do sítio Domingos.

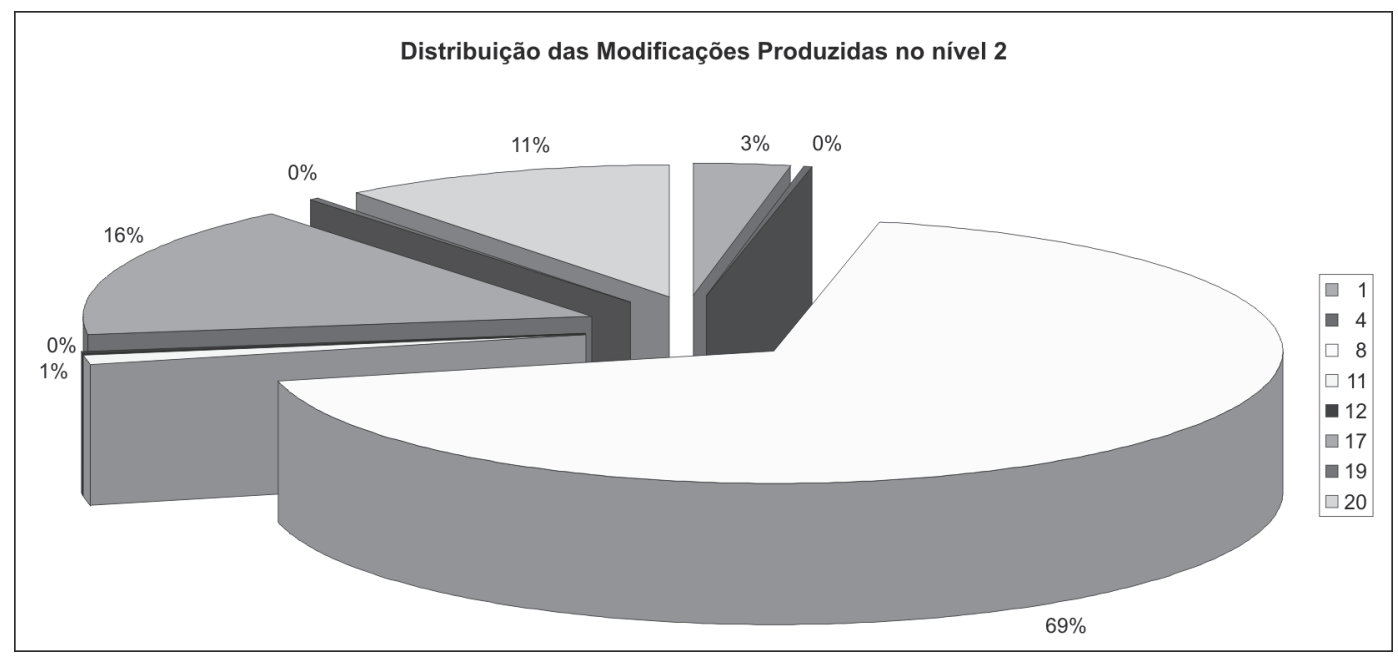

Fig. 8b. Gráfico da distribuição das modificações produzidas no nível 2 do sítio Domingos.

evidente, com maior representação das modificações associadas às ações de percutir, esmagar, triturar (56\%) do que às ações de cortar e raspar (44\%).

No nível 2, além de haver um número bem menor de tipos de modificações representados, diminuem significativamente os vestígios modificados pela ação térmica. A maioria dos vestígios desse nível não indicou nenhum tipo de modificação, tendo sido apropriados de forma bruta. Há dois tipos de modificação com uma represen- tação significativa nesse nível e que estão associados exclusivamente aos vestígios utilizados no processo de lascamento bipolar, especificamente percutores (com marcas de picoteamento) e bigornas (com marcas de estrias e orifícios). Excluindo esses tipos de modificação, apesar da baixa representatividade, predominam absolutamente os vestígios com modificações associadas às atividades de cortar e raspar, estando praticamente ausentes aqueles associados às atividades de triturar, esmagar ou pilar. 
A distribuição dos vestígios indica também uma diferença entre os níveis 1C e 2 (Figs. 9a e $9 b)$. Apesar de em ambos os níveis predominarem os fragmentos, no nível 1C eles representam $71 \%$ dos vestígios coletados enquanto no nível 2 apenas 36\%. Essa diferença faz com que no nível 2 haja uma representação mais equânime entre os tipos de vestígio do que no nível 1C. Assim, também apesar de nos dois níveis o segundo tipo de vestígio melhor representado ser o dos artefatos, no nível 2 eles somam 24\%, enquanto no nível $1 \mathrm{C}$ apenas $10 \%$. Cabe lembrar aqui que a porcentagem dessa classe de vestígio no nível 2 está super-representada pelos percutores e bigornas utilizados no lascamento bipolar e posteriormente descartados. $\mathrm{O}$ mesmo acontece com os núcleos, que aparecem com um porcentual mais elevado no nível 2 do que no nível 1C. Já no que diz respeito às lascas, apesar de serem o tipo de vestígio com menor representação no nível 2, seu percentual no conjunto dos vestígios é superior ao do nível $1 \mathrm{C}$, onde aparecem como o terceiro tipo de vestígio melhor representado.

A partir desses dados vemos que há diferenças significativas entre os níveis principalmente

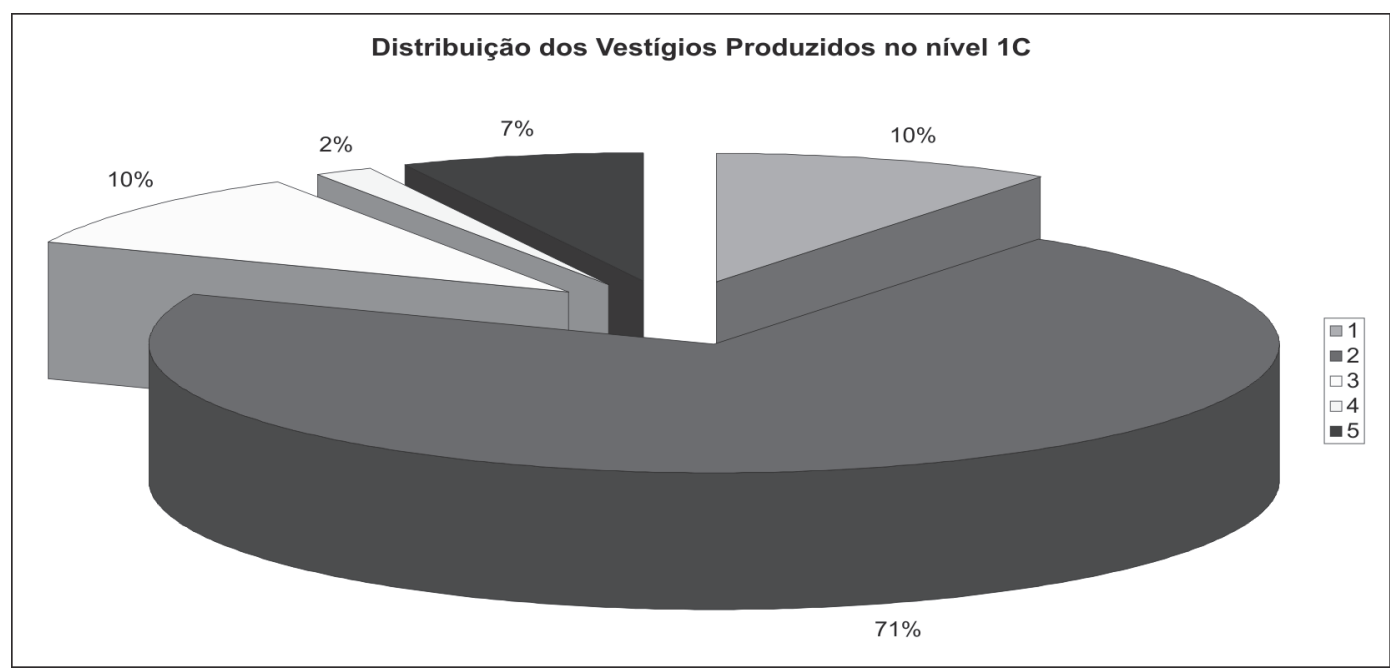

Fig. 9a. Gráfico da distribuição dos vestígios produzidos no nível 1C do sítio Domingos.

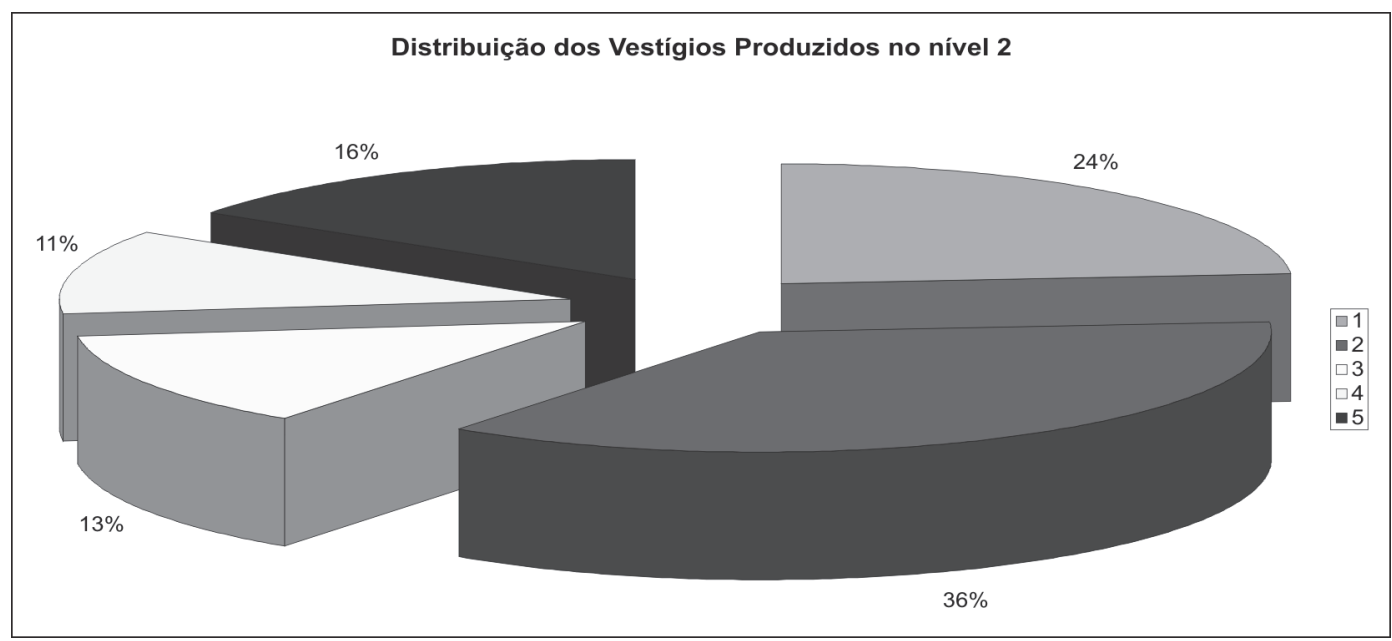

Fig. 9b. Gráfico da distribuição dos vestígios produzidos no nível 2 do sítio Domingos. 
com relação às matérias-primas utilizadas e as modificações produzidas, mais do que no que diz respeito às técnicas utilizadas e os vestígios gerados. Dessa maneira, essa composição nos permite levantar a hipótese de que cada um desses níveis representa distintas camadas de ocupação, embora seja ainda precipitado afirmar se as diferenças identificadas estão associadas a ocupações por grupos distintos ou são decorrentes da realização de diferentes funções em cada período de ocupação. Para encaminhar essa questão é necessário que se faça o cruzamento dos atributos a fim de verificar se há ou não continuidades na forma de apropriação de cada matéria-prima em específico e, se possível, caracterizar a cadeia operatória associada à produção dos poucos artefatos formalmente modificados. Além disso, é preciso lembrar que a hipótese apresentada acima está formulada apenas com base na análise do material lítico e, portanto, pode e deve ser confrontada com as informações obtidas com os demais vestígios presentes no sítio para que possa ser confirmada ou contestada.

\section{Distribuição do material lítico no espaço e os indicadores de áreas de atividade}

Tendo em vista a quantidade, a diversidade e as características associadas aos tipos de modificação identificados no conjunto de vestígios líticos coletados no nível $1 \mathrm{C}$, procuramos fazer uma análise de sua distribuição espacial no sítio a fim de verificar a possibilidade de identificação de áreas de atividade. Há dois aspectos especialmente importantes no que diz respeito aos tipos de modificação: predominância das alterações causadas pelo fogo e presença de uma grande variedade de modificações possivelmente associadas ao tratamento de matéria-prima vegetal. Esses dois tipos de modificação, principalmente quando associados, podem indicar a localização de áreas domésticas, nas quais as atividades de processamento de alimentos seriam realizadas. Ainda outro conjunto de vestígios que poderia indicar também a realização de atividades associadas a áreas domésticas estaria representado por aqueles vestígios que associamos ao processo de produção da cerâmica que incluem, além da fabricação de antiplástico mineral o processamento e a utilização de corantes.

O primeiro aspecto a ser observado envolve a distribuição geral dos vestígios pelas áreas de escavação (Fig. 10). Para calcular essa distribuição somamos o total de vestígios líticos coletados em cada área de escavação e dividimos pela área escavada $\mathrm{em} \mathrm{m}^{2}$ a fim de obter uma medida que compare não a quantidade absoluta de vestígios, mas a densidade por $\mathrm{m}^{2}$. Utilizamos nesse caso informações sobre as escavações realizadas em junho de 2004, setembro de 2004 e agosto de 2005, para as quais todos os dados referentes à quantidade e localização dos vestígios líticos já foram organizados.

De acordo com essa distribuição as áreas de escavação com maior densidade de material lítico foram respectivamente as seguintes: 35 , $26,47,25,29,28,36,43,58$ e 45 . Se observarmos a distribuição dessas áreas no sítio veremos que estão localizadas na parte mais periférica da área trabalhada, distribuídas pelos quatro quadrantes do sítio. Já as áreas onde encontramos a menor densidade de vestígios foram, em ordem crescente, as seguintes: 61 , $60,59,57,41,37 \mathrm{~A}, 33,48,49,31$ e 10. Apesar de estarem distribuídas por diversas áreas do sítio, dentre as áreas de menor densidade há dois dos locais com maior área escavada no que seria a parte central do sítio. Cruzando esses dados poderíamos definir uma distribuição diferencial no que se refere à densidade de vestígios líticos entre centro (densidade baixa) e periferia (densidade alta).

Como até o momento realizamos a análise de uma amostra do material lítico do sítio, não há como comparar a composição artefatual de cada uma dessas áreas. No entanto, a amostra analisada engloba tanto porções periféricas quanto porções centrais do sítio e, dessa maneira, podemos explorar a comparação entre elas a fim de avançar na identificação de áreas de atividade.

Quanto à matéria-prima, predomina nesse nível, em praticamente todas as áreas de escavação, a matéria-prima outros, com exceção, 


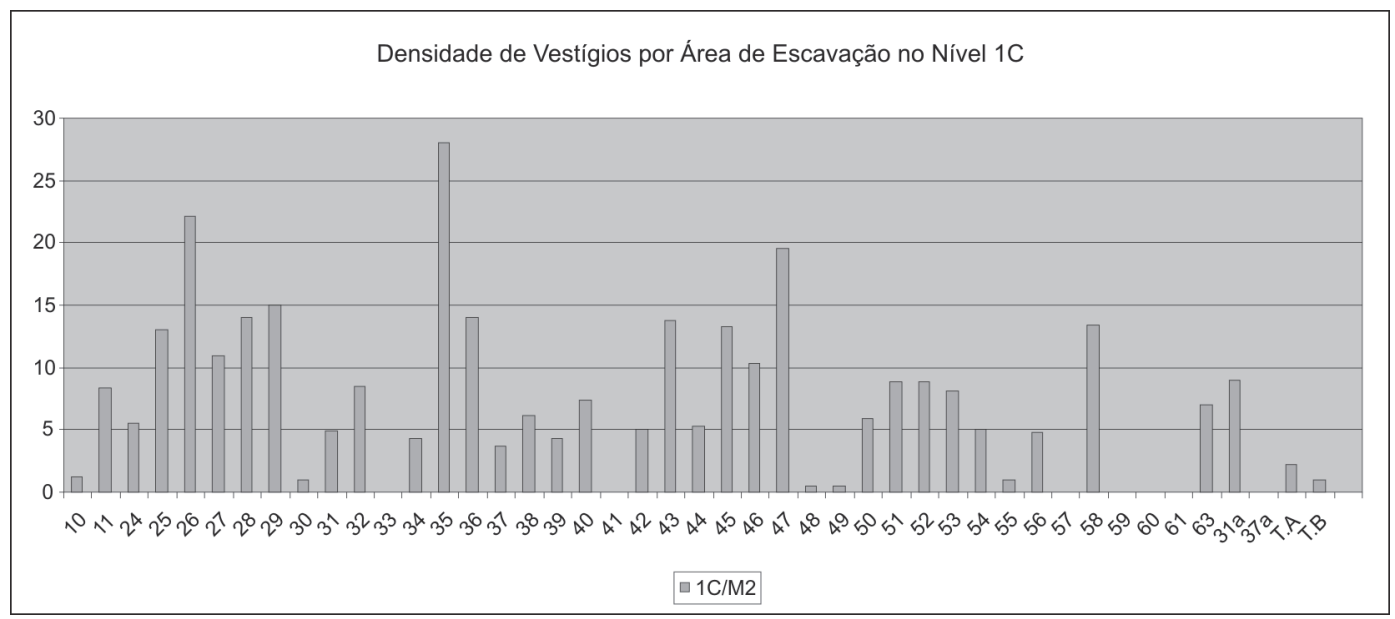

Fig. 10. Gráfico da densidade de vestígios por área de escavação no nível 1C do sítio Domingos.

principalmente, da área 37 onde predomina o quartzo. As demais áreas onde isso também ocorre apresentam poucos vestígios e, portanto, são pouco representativas para a atual discussão (Fig. 11).

Entre as técnicas de transformação predomina em todas as áreas de escavação a apropriação bruta. A utilização de técnicas de lascamento uni e bipolar aparecem melhor representadas na área de escavação 37, mas estão presentes também em áreas como a 50 e a 58. O polimento aparece em apenas cinco áreas de escavação e sempre com baixa representatividade (Figura 12).

Para a distribuição dos vestígios gerados há também a predominância de uma determinada variável em todas as áreas de escavação que corresponde aos fragmentos. Excetuando-se essa variável encontramos uma maior diversidade entre as áreas com maior quantidade de vestígios. A área 37 apresenta, por exemplo, maior quantidade de lascas, seguidas pelos

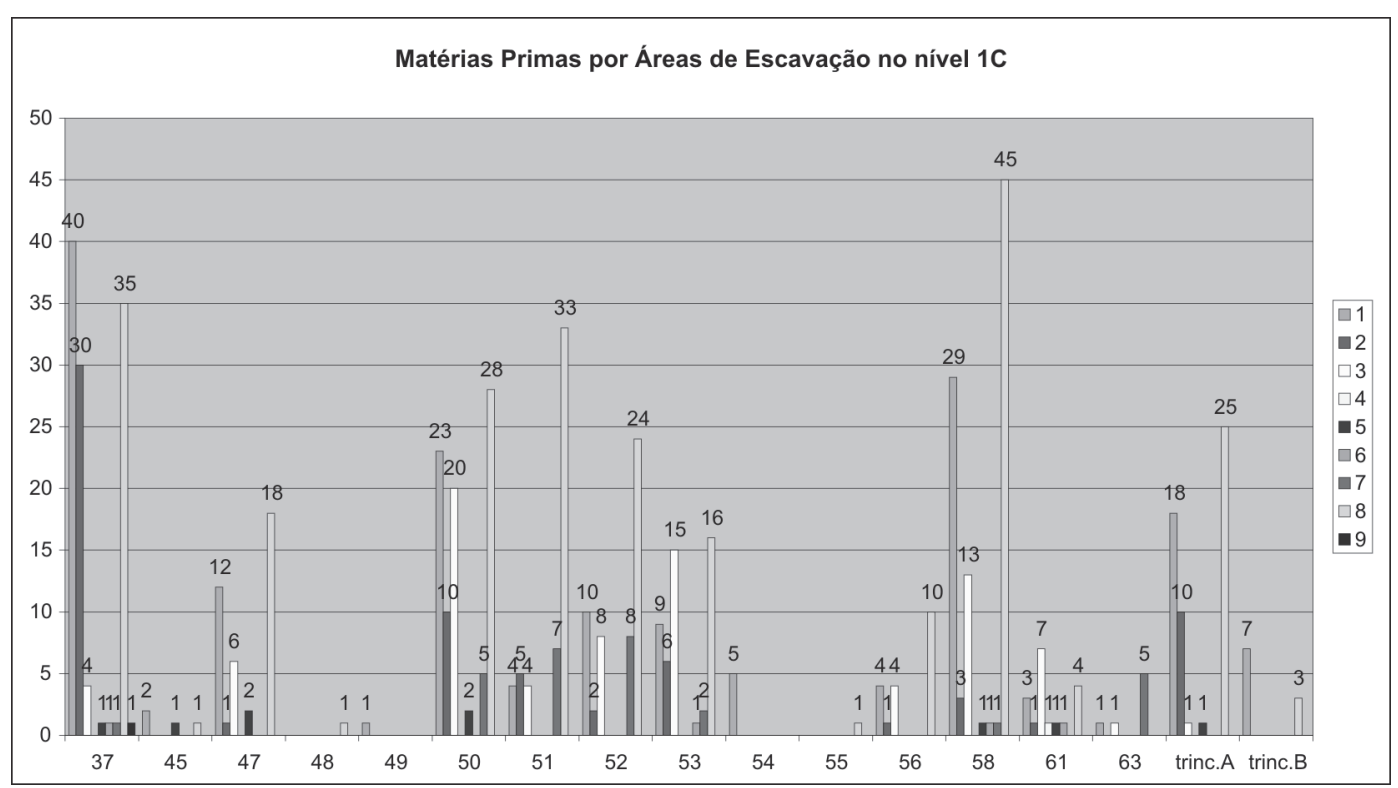

Fig. 11. Gráfico de matérias-primas por área de escavação no nível 1C do sítio Domingos. 


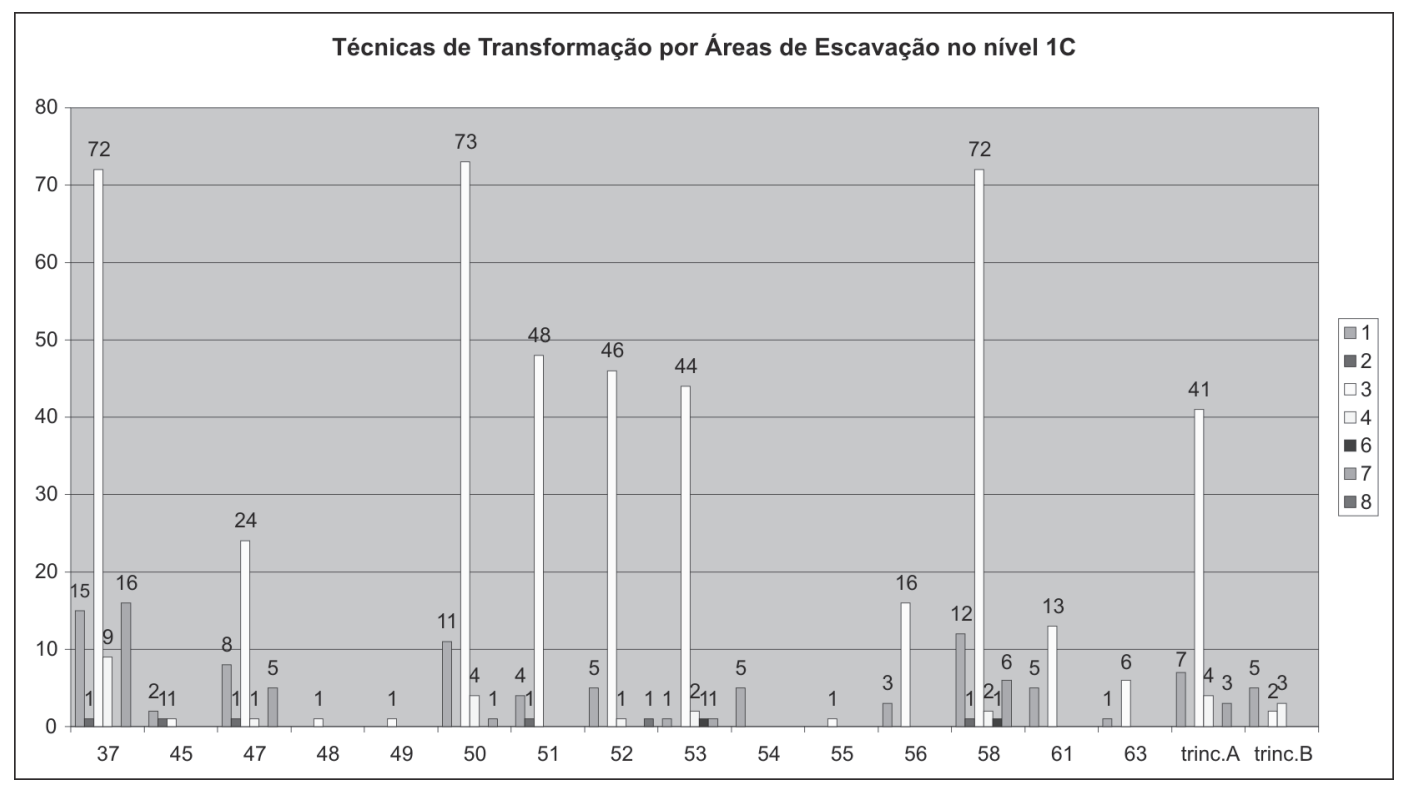

Fig. 12. Gráfico das técnicas de transformação por áreas de escavação no nível 1C do sítio Domingos.

vestígios brutos e pelos artefatos, enquanto as áreas 50 e 53 apresentam mais artefatos, seguidos por vestígios brutos e depois pelas lascas. Já na área 58 predominam os brutos, seguidos pelas lascas e depois pelos artefatos (Fig. 13).
Se observarmos a distribuição das modificações produzidas ainda é uma única variável que predomina em todas as áreas, a da modificação causada pela ação térmica (Fig. 14). A única exceção nesse caso está representada pela área de escavação 37. Se analisarmos a distri-

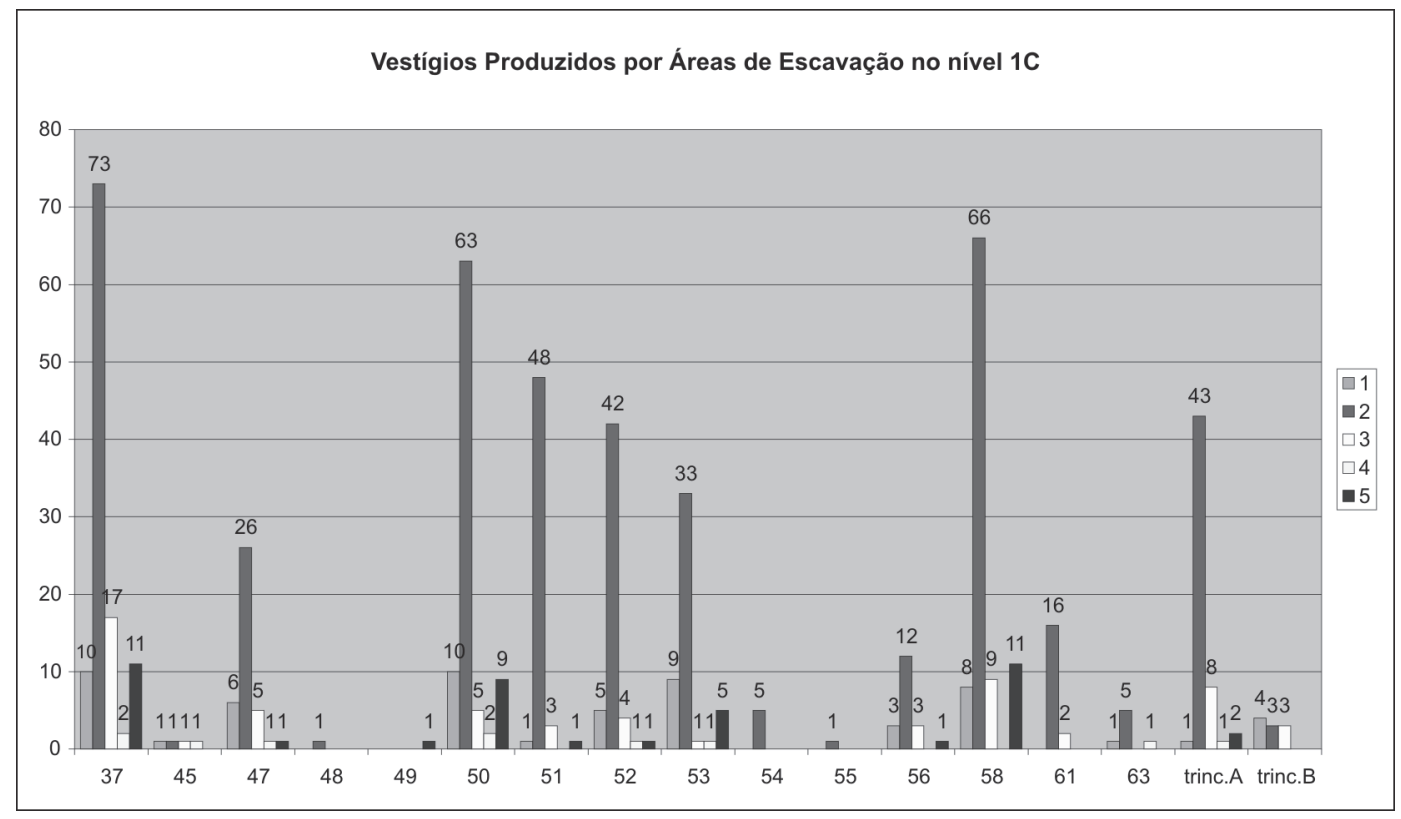

Fig. 13. Gráfico de vestígios produzidos por área de escavação no nível 1C do sítio Domingos. 
buição das modificações produzidas sem considerar a queima, predominam em todas as áreas os vestígios sem modificação alguma, que no caso específico da escavação 37 chegam a mais de 90\% . Para a distribuição das modificações associadas aos artefatos encontrados nesse nível encontramos uma certa variedade na composição dos conjuntos de cada área. Nas áreas $50 \mathrm{e}$ 58 , por exemplo, predominam os artefatos onde houve a produção de superfícies planas e alterações térmicas, enquanto na área 37 predominam os artefatos nos quais houve a produção de um gume. Já as áreas de escavação 52 e 53 apresentam uma boa diversidade de tipos de modificação, todas associadas a atividades que envolvem ações de triturar, esmagar e pilar.

Apesar de ainda preliminares, as informações acerca da distribuição dos vestígios no sítio parecem reforçar a hipótese apresentada no início deste tópico a respeito da existência de uma oposição entre centro (representado na amostra analisada principalmente pela escavação 37) e periferia (representado pela maioria das demais áreas de escavação até o momento analisadas e com coleções significativas no nível 1C). Apesar de haver a princípio uma certa homogeneidade entre as áreas de escavação, sempre que há uma discordância, a área que destoa do padrão é a área 37. Entre as demais áreas há também pequenas diferenças que parecem estar mais relacionadas a aspectos quantitativos do que qualitativos, o que de certa maneira reforça a hipótese de que essas áreas periféricas possam representar áreas de atividade doméstica, ou seja, de realização de atividades semelhantes que envolvem dessa maneira conjuntos artefatuais semelhantes, mas distribuídos em proporções distintas devido à composição do grupo doméstico.

Como já ressaltamos para que as hipóteses apresentadas acerca tanto da existência de diferentes camadas de ocupação quanto de diferentes áreas de atividade neste sítio sejam testadas, é fundamental que se faça o cruzamento das informações geradas a partir da análise dos vestígios líticos com aquelas oriundas das análises dos demais vestígios coletados. O que propusemos aqui é, por enquanto, uma interpretação sobre alguns aspectos associados à ocupação do sítio Domingos baseada exclusivamente na análise do material lítico e que tem como um dos seus principais objetivos ressaltar a importância e o

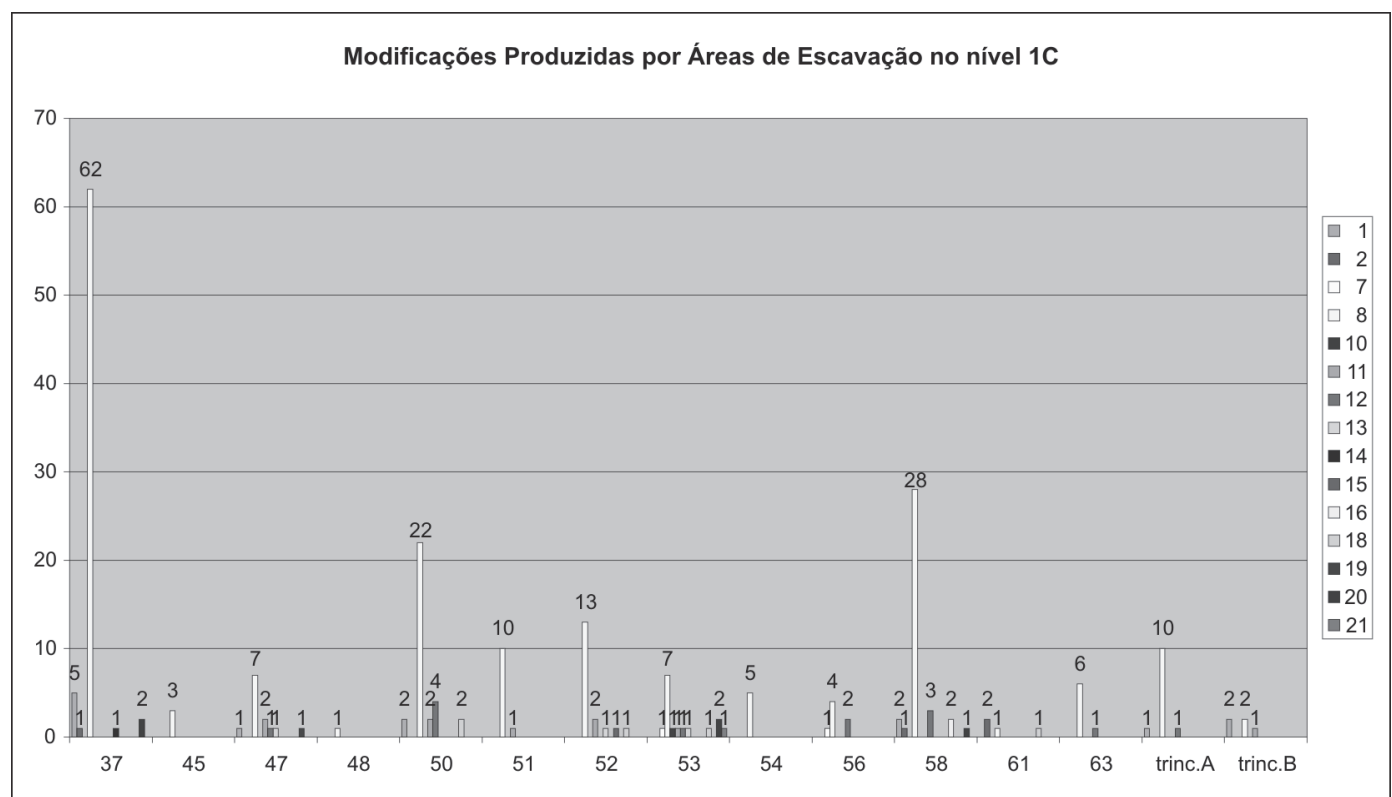

Fig. 14. Gráfico de modificações produzidas por área de escavação no nível 1C do sítio Domingos. 
potencial da análise de tais vestígios em contextos ceramistas.

\section{Artefatos}

Os artefatos encontrados no sítio Domingos podem ser agrupados em duas grandes categorias: artefatos passivos (que recebem a força aplicada na ação) e artefatos ativos (aqueles pelos quais se aplica a força). A partir das variáveis utilizadas para caracterizar as modificações produzidas em cada artefato podemos separá-los, dentro dessas grandes categorias, em três conjuntos: artefatos brutos, artefatos polidos, artefatos lascados. Os artefatos lascados são sempre ativos, enquanto os polidos e os brutos podem ser tanto ativos quanto passivos.

$\mathrm{Na}$ amostra analisada há um total de 166 artefatos que podem ser assim distribuídos: 56 $\%$ são artefatos ativos e $44 \%$ passivos. Dos ativos, $45 \%$ são brutos, $44 \%$ lascados, $8 \%$ polidos e $3 \%$ polidos e lascados. Dos passivos, $96 \%$ são brutos e $4 \%$ polidos. Entre os artefatos brutos ativos estão os percutores (usados no lascamento uni e bipolar) e batedores (relacionados ao processamento de vegetais), entre os lascados estão as lascas retocadas e/ou simplesmente utilizadas e entre os polidos e polidos e lascados se encontram as lâminas de machado. Já os artefatos passivos incluem as bigornas utilizadas no lascamento bipolar e os suportes para processamento de vegetais (Fig. 15).

Observando a distribuição dessas categorias e conjuntos em estratigrafia há alguns aspectos que podem ser destacados. O nível 2 é o que apresenta o maior número de artefatos, com a mesma proporção de ativos e passivos. $\mathrm{O}$ nível $1 \mathrm{C}$ vem em segundo lugar, com uma predominância de artefatos ativos (35) sobre os passivos (25). Na seqüência aparece o nível 1D, com mais ativos (5) que passivos (4) e as camadas 1A, 1B e superfície com pouquíssimos artefatos. Com relação aos conjuntos, no nível 2 predominam os artefatos brutos, seguidos pelos lascados, com apenas um artefato polido e lascado. No nível $1 \mathrm{C}$ a proporção entre as categorias é mais equilibrada, mas continuam a prevalecer os brutos, seguidos pelos lascados, havendo, no entanto, também artefatos polidos e lascados e polidos. Um dado bastante significativo é o fato de que os artefatos polidos aparecem em todos os níveis, inclusive a superfície, com exceção apenas do nível 2 e se concentram no nível 1C. Outro elemento importante de comparação entre os níveis envolve os conjuntos que compõem a categoria de artefatos ativos nos níveis $1 \mathrm{C}$ e 2 . Enquanto no nível $1 \mathrm{C}$ predominam os ativos lascados, seguidos pelos ativos brutos, no nível 2 essa relação se inverte, havendo uma preponderância de artefatos ativos brutos sobre os ativos lascados.

Mais uma vez, essa diferença na composição do conjunto de artefatos entre os níveis 1C e 2 reforça a hipótese já apresentada de que teríamos duas ocupações distintas associadas a cada uma dessas camadas. Nesse caso, além de diferenças quantitativas há também diferenças qualitativas, com a presença da utilização de uma técnica de produção de artefatos em apenas uma das camadas, como é o caso do polimento. Por outro lado, a observação da distribuição das modificações produzidas que caracterizam o conjunto de artefatos passivos e ativos da camada 2 indica uma certa especialização, com predomínio absoluto, entre os artefatos passivos, de modificações decorrentes do lascamento bipolar. Ou seja, a grande maioria dos vestígios caracterizados como artefatos na camada 2 está associada ao lascamento bipolar, constituindose predominantemente de bigornas, mas também de percutores. Assim, apesar de tanto a camada $1 \mathrm{C}$ quanto a camada 2 compartilharem, de modo geral, um mesmo padrão de apropriação das matérias-primas, há conjuntos de artefatos associados a diferentes atividades que se distribuem de forma diferencial entre as camadas, sendo responsáveis pela diferenciação destas.

Quanto ao processo de produção e utilização dos artefatos, há poucos elementos que possam ser explorados, a não ser o fato de que só há produção de artefatos polidos, conjunto este composto essencialmente por lâminas de machado, dentre os artefatos da camada 1C. Entre essas lâminas de machado 

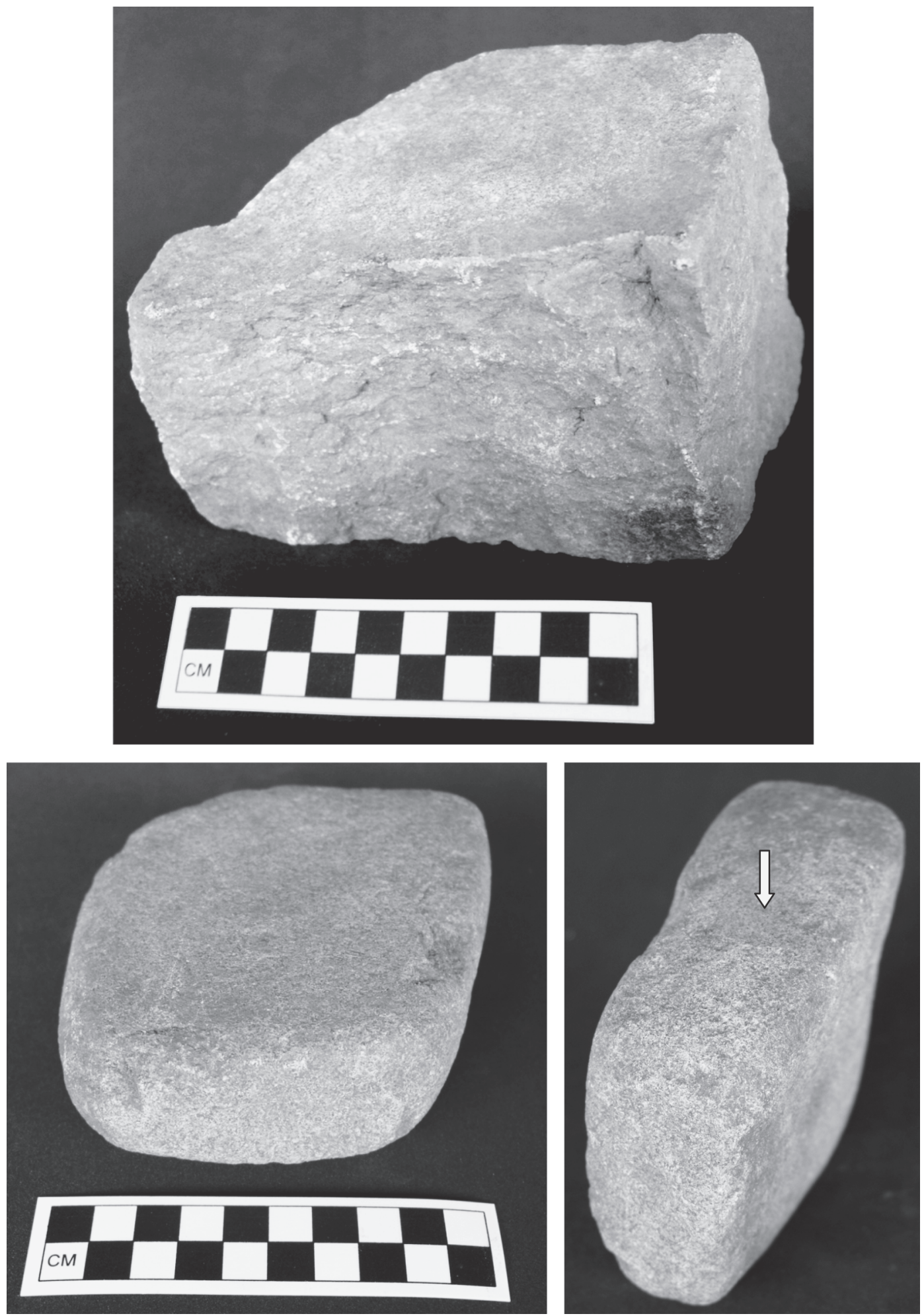

Fig. 15. Prancha com artefatos brutos passivos, com superfícies alisadas e orifício. 
predominam as de formato retangular, produzidas por picoteamento e polimento, mas há também lâminas com ombro (ou orelha) finamente polidas.

Dentre os artefatos lascados, predomina uma exploração totalmente expediente de lascas total ou parcialmente corticais. Praticamente não há retoques, utilizando-se um ou mais bordos da lasca como gume, ao qual, normalmente se opõe um bordo mais espesso ou também cortical que serve para preensão. Todos os artefatos lascados parecem ter sido utilizados por preensão direta, não havendo em nenhum caso indícios de encabamento para tais artefatos.

Com relação à distribuição dessas categorias (ativo e passivo) e conjuntos (bruto, lascado e polido) na camada $1 \mathrm{C}$, os únicos setores de escavação onde predominam os artefatos passivos sobre os ativos são 50 e 58 ; nos setores $37,47,52$ e 53 , ambas as categorias estão presentes, mas prevalecem os ativos sobre os passivos; enquanto nos setores 45 , 51, trincheira A e trincheira B estão presentes apenas os artefatos ativos.

\section{Processo de formação do sítio Domingos: hipótese preliminar}

A partir da caracterização tecnológica do conjunto de vestígios líticos encontrado no sítio Domingos e de sua distribuição espacial, podemos levantar uma hipótese preliminar sobre o processo de formação deste sítio. Essa hipótese, por sua vez, pode e deve ser testada com a continuidade dos trabalhos de análise do material lítico e, principalmente, com o cruzamento dos dados oriundos das análises realizadas para os demais vestígios encontrados no sítio. Outro elemento fundamental para o teste dessa hipótese envolve a obtenção de um conjunto de datas associadas a diferentes locais e diferentes camadas estratigráficas.

Segundo vimos, há dentre o material lítico estudado evidências contundentes para distinção de, ao menos, dois momentos de ocupação deste sítio, o primeiro deles associa- do aos vestígios inseridos na camada 2 e o segundo aos vestígios da camada $1 \mathrm{C}$.

A ocupação da camada 2 apresenta como características principais (em termos de composição absoluta e comparativamente à camada 1C) uma alta freqüência de utilização das matérias-primas quartzo e quartzito, de preferência na forma de seixo ou nódulo, apropriados através do lascamento, seja ele uni ou bipolar. Quanto aos artefatos, apesar de a proporção entre ativos e passivos ser a mesma, para ambas as categorias predomina o conjunto de artefatos brutos, ou seja, mesmo entre os artefatos ativos a grande maioria foi utilizada sem modificação prévia. Dentre aqueles que foram modificados para serem utilizados, praticamente só há artefatos lascados nos quais se aproveitou um gume bruto da lasca. Mas o conjunto de vestígios mais característico dessa camada engloba os artefatos utilizados no lascamento bipolar percutor e bigorna. Esses vestígios são característicos não só pela sua quantidade (em termos proporcionais no conjunto de vestígios dessa camada), mas também pela sua localização e disposição espacial - encontrando-se na maioria associados entre si, formando um grande conjunto de seixos numa área específica do sítio.

Uma característica bastante peculiar desse conjunto envolve o fato de muitos dos seixos utilizados como núcleos, percutores ou bigornas, serem de um quartzito grosseiro que se mostra com uma baixa aptidão ao lascamento, em decorrência do que muitos desses seixos se encontram fragmentados ou com pouquíssimos negativos de lascamento. No entanto, em meio a esses seixos de matéria-prima de baixa qualidade, há alguns exemplares de quartzo e mesmo de quartzito que se mostram mais aptos ao lascamento e que, nesses casos, produzem um número maior de lascas aproveitáveis. Já os seixos cuja matéria-prima é um pouco melhor (apesar de ainda ser quartzo ou quartzito) a técnica utilizada para obtenção das lascas é a unipolar.

Dessa maneira, vemos que os artesãos que estavam lascando esses seixos detinham o conhecimento dos gestos e procedimentos 
técnicos para efetuar tanto um lascamento unipolar quanto bipolar e que escolhiam qual dos dois procedimentos utilizar em função da qualidade da matéria-prima em termos de resposta ao lascamento. No entanto, dentre os vestígios produzidos através de qualquer uma das técnicas, não há evidências de uma exploração intensa dos núcleos ou de um preparo deste com vistas à obtenção de um produto específico. Isso é corroborado pelas próprias características dos artefatos, compostos por lascas ainda com superfície cortical, nas quais houve o aproveitamento de um gume sem a necessidade de realização de retoques.

Nesse sentido, podemos pensar que os vestígios associados à camada 2 indicam uma ocupação deste sítio voltada especialmente para exploração dos seixos, cuja fonte seria o leito do rio Parauapebas, a pouco mais de cem metros de distância de onde o sítio se encontra atualmente. Há ainda evidências na porção mais a oeste do sítio (especificamente setor de escavação 31) de que o rio Parauapebas estivesse ainda mais próximo ao sítio do que se encontra atualmente, levantando assim a possibilidade de que neste momento o sítio fosse utilizado como fonte de matéria-prima. Os seixos seriam obtidos no local e lascados para obtenção de lascas com gume cortante, dentre as quais algumas seriam utilizadas no próprio sítio e outras possivelmente transportadas para outros locais. Nesse caso, o conjunto de seixos identificados no setor de escavação 37 seria o refugo do lascamento, correspondendo a uma área de descarte de seixos lascados e testados para verificação da qualidade da matéria-prima e obtenção de poucas lascas.

Em função da quantidade e dispersão do material lítico nessa camada o sítio não deve ter sido ocupado intensamente, sendo fruto de incursões ocasionais. Após o seu abandono houve acúmulo de sedimento provavelmente por ocasiões de cheia intensa do rio, formando uma camada de areia com espessura variável que, na estratigrafia do sítio corresponde à camada 1D. Enquanto se aguarda o resultado de datações absolutas tanto para a camada 2 quanto para a $1 \mathrm{C}$, talvez um estudo mais específico de micromorfologia pudesse identificar a origem do sedimento correspondente a camada 1D e sua possível relação com eventos de cheia do rio que, por sua vez, poderiam ajudar a estimar um tempo mínimo de duração para formação desse pacote sedimentar.

Transcorrido esse período teria tido início a ocupação associada aos vestígios encontrados na camada 1C. Não há ainda como avaliar o início desse processo e se os vestígios da camada 1D corresponderiam a um momento inicial dessa ocupação ou ao soterramento dos vestígios pela simples ação de pisoteio e circulação. Além disso, mesmo as diferentes áreas do sítio associadas à camada $1 \mathrm{C}$ podem ter datações diferentes, indicando modificações na estrutura de ocupação espacial do sítio, com o crescimento da população envolvida nesse processo ou a modificação e alternância entre áreas de habitação e de circulação pública.

De qualquer forma a caracterização e distribuição espacial dos vestígios líticos indicam a existência de uma ordenação no processo de utilização do espaço, com áreas diferenciadas para realização de determinadas atividades. Assim, pudemos esboçar uma oposição entre centro e periferia, sendo o primeiro caracterizado por uma baixa densidade de vestígios em geral e de vestígios possivelmente associados a atividades envolvendo o uso do fogo, processamento de vegetais e produção cerâmica; atividades estas melhor representadas nos setores de escavação localizados no que consideramos como periferia do sítio.

Além disso, a presença de uma maior variedade de matérias-primas utilizadas e de formas de apropriação e modificação dessas matérias-primas aponta para uma diversificação das atividades realizadas, incluindo exploração de fontes de matéria-prima diversificadas e produção de artefatos polidos, como machados, in situ. A presença de uma série de artefatos brutos ativos e passivos aponta ainda para o incremento das atividades associadas ao processamento vegetal, fato este que pode ser corroborado também pela formação de um espesso pacote de terra preta em algumas áreas do sítio, certamente envolvendo um acúmulo intenso de matéria orgânica. 
Ainda um aspecto associado ao processo de formação desse sítio que pode ser inferido pela análise do material lítico envolve a cobertura vegetal durante sua ocupação. Em função da quantidade, tamanho e peso dos machados e das características de seus gumes, podemos dizer que sua utilização não deve ter sido intensa e esteve associada à retirada de árvores de pequena espessura. Essas características associadas às evidências de um uso intenso do fogo, levantam a possibilidade de que a área na qual o sítio foi estabelecido tenha sido "aberta" principalmente através da queimada da vegetação ali presente e que esta vegetação provavelmente já seria de origem secundária, contando com a presença de árvores não muito grandes e espessas, características da capoeira.

Outro aspecto que pode ser inferido pelas características dos machados envolve a existência de uma possível diferenciação social e utilização desse artefato como indicador de status. Há entre os machados com e sem sinal de uso uma diferença muito marcante no que diz respeito ao grau de acabamento e à produção de um efeito estético. Enquanto os machados utilizados apresentam áreas picoteadas, polimento superficial e gumes não muito simétricos, os machados sem marcas de utilização estão totalmente polidos, são perfeitamente simétricos e confeccionados em outras matériasprimas; um deles, aliás, foi encontrado junto a um dos sepultamentos e apresenta dimensões por demais reduzidas para que pudesse ser utilizado (Figs. 16 e 17).

No que se refere ao que denominamos como "área periférica", esta não pôde ser ainda muito bem compreendida no sentido de definir com mais clareza os limites e, possivelmente o número de unidades habitacionais a fim de identificar uma possível forma para a estruturação do espaço interno do sítio. Com isso não nos é possível ainda caracterizar o processo de formação do sítio relacionado à dinâmica de ocupação correspondente a essa camada 1C. Esse aspecto, no entanto, certamente poderá ser melhor discutido com a inserção dos dados oriundos da análise cerâmica e da distribuição dos enterramentos.
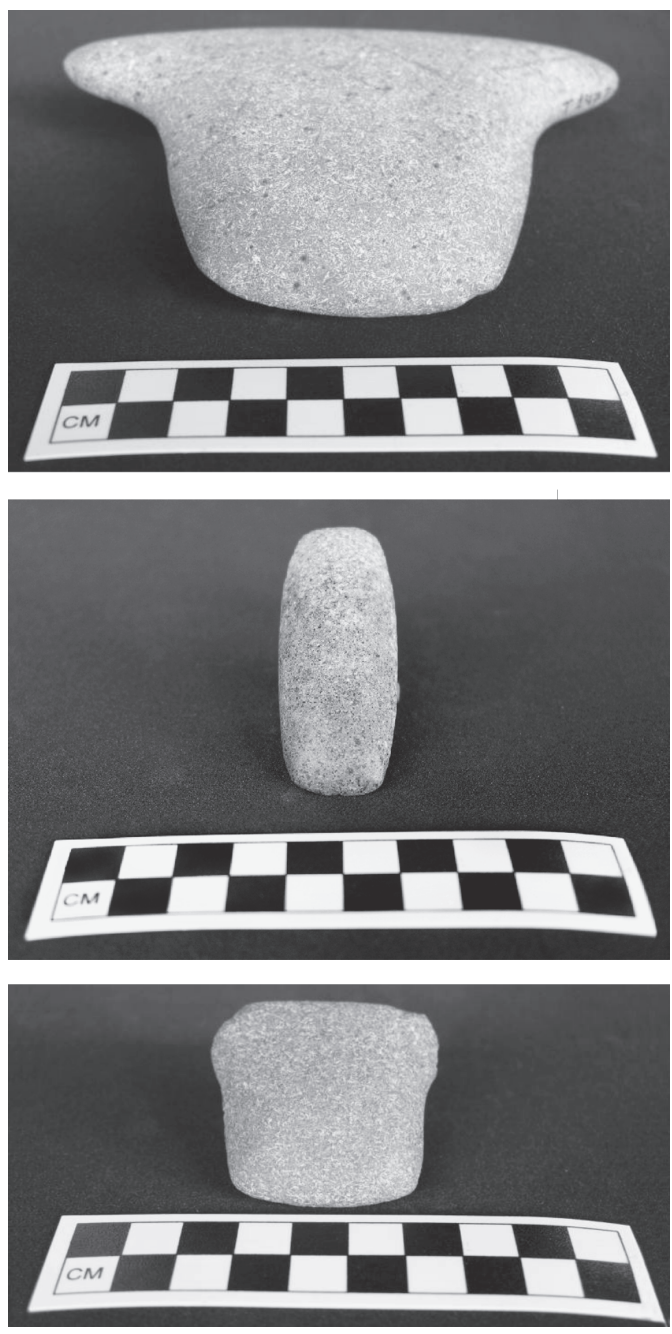

Fig. 16. Prancha com lâminas de machado polidas e sem marcas de uso. A lâmina da foto do meio foi encontrada junto a uma urna.

Assim como o início da ocupação, seu término também é de difícil caracterização. Aparentemente, a parte principal da ocupação se encontra na camada $1 \mathrm{C}$, sendo as camadas $1 \mathrm{~B}$ e $1 \mathrm{~A}$ formadas após o abandono do sítio. No entanto, como sugerimos para a camada $1 \mathrm{D}$, as camadas $1 \mathrm{~B}$ e $1 \mathrm{~A}$ podem também corresponder a um processo de abandono gradual, com a diminuição no tamanho da população envolvida e, conseqüentemente, diminuição na freqüência das atividades realizadas e na quantidade de vestígios materiais gerados. 

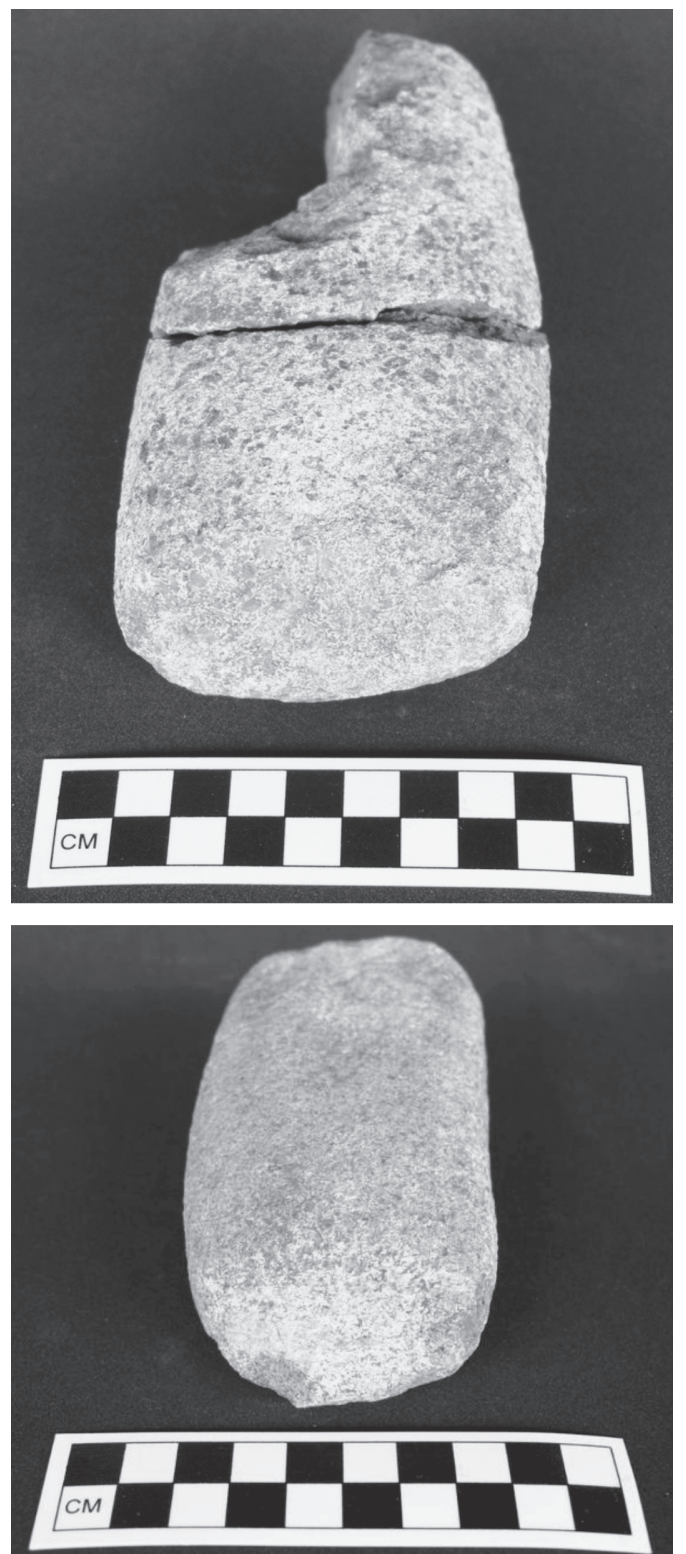

Fig. 17. Prancha com lâminas de machado picoteadas, com polimento restrito ao gume e com marcas de utilização.

\section{Conclusão: potencialidades e perspectivas}

Conforme apresentado, com a metodologia proposta e a amostra selecionada foi possivel caracterizar a indústria lítica do sítio Domingos e dessa maneira fornecer elementos para estabelecer uma comparação com outros contextos da região e levantar hipóteses a respeito dos tipos e locais das atividades que estavam sendo realizadas no sítio, além da possibilidade de ele compreender mais de uma camada de ocupação. A partir dessa contextualização, novos problemas surgiram e apontam para a necessidade da continuidade dos trabalhos.

\section{A(s) ocupação(ões) do sítio Domingos}

No caso específico do sítio Domingos, os dados levantados apontam não só para a necessidade, mas também para a relevância da continuidade dos trabalhos de análise dessa coleção para que se compreenda de forma mais detalhada o processo de formação desse sítio. Essa continuidade envolve tanto trabalhos de laboratório quanto de escavação. Esse último ponto é fundamental principalmente para o encaminhamento da questão associada à existência de duas ocupações no sítio Domingos. Para averiguar a relevância dessa hipótese é necessário que se façam novas escavações em diferentes áreas, talvez até para além do limite definido pela distribuição espacial dos vestígios associados à camada $1(1 \mathrm{~A}, 1 \mathrm{~B}, 1 \mathrm{C}$ e $1 \mathrm{D})$, que se amplie a profundidade de áreas já escavadas, que se obtenha uma amostra maior de material lítico associado a essa camada e, principalmente, que se obtenham amostras de carvão ou lítico queimado que possam ser datadas. $\mathrm{Na}$ ausência de tais amostras, seria interessante realizar um estudo de micromorfologia a fim de entendermos um pouco melhor o processo de deposição associado à camada 1D, que corresponderia ao intervalo das duas ocupações identificadas no sítio.

Com relação aos trabalhos de laboratório, o teste da hipótese levantada acerca da existência de uma oposição entre centro e periferia faz com que seja necessário complementar a análise do material coletado, trabalhando com o total de vestígios identificados em cada área de escavação. Esse procedimento, aliado ao cruzamento de dados oriundos das análises dos demais tipos de vestígio encontrados no sítio Domingos, pode fornecer elementos mais consistentes para compreensão e caracterização das diferentes atividades realizadas no sítio e sua distribuição espacial. 
Com relação a esse ponto, é preciso reforçar que um dos principais fatores que possibilitaram investigar esse tipo de informação foi a metodologia de campo adotada para escavação do sítio. $\mathrm{O}$ cruzamento de dados oriundos da aplicação de métodos geofísicos e da realização de tradagens, utilizados para orientar a localização das áreas de escavação, as quais tiveram, na maioria das vezes, sua extensão definida pelas características distribucionais e relacionais dos vestígios possibilitou não só a investigação de diferentes áreas do sítio, como a caracterização detalhada do conjunto artefatual presente em cada um desses locais, que, por sua vez, constituem-se num importante vetor de informação sobre a natureza das atividades aí realizadas.

\section{O material lítico no âmbito dos estudos de tecnologia lítica}

Um primeiro ponto que pode ser levantado diz respeito à composição da amostra e à importância de a análise contemplar todo o conjunto de vestígios. Como vimos para o sítio Domingos, grande parte do material lítico presente no sítio foi apropriada de forma bruta, sendo que uma grande parte destes vestígios brutos apresentam marcas de queima com intensidades variadas, que vão desde a presença de algumas cúpulas térmicas e mudança de coloração até a fragmentação por completo, o que já foi ressaltado por outros pesquisadores em sítios cerâmicos na Amazônia (Costa 2002). Isso aponta para um aspecto importante e particular destes contextos que traz informações a respeito da principal utilização do material lítico: organizar, definir e delimitar espaços. Apesar de não haver construções de grande porte realizadas com a utilização da pedra, nestes contextos a maioria dos vestígios líticos são procurados e obtidos no entorno imediato do sítio, trazidos para o sítio e utilizados para construção de estruturas de combustão que servem a diferentes propósitos e que, por conseguinte, têm diferentes composições. Além disso, esses mesmos vestígios podem ser utilizados como uma espécie de mobília no desempenho de outras tarefas, que não causam nenhum tipo de alteração química ou física identificável no registro arqueológico. De qualquer maneira, esse tipo de atividade compõe aquilo que podemos denominar de Economia de MatériaPrima, o que envolve o conjunto das estratégias utilizadas para obter, gerir e utilizar um tipo de recurso específico - matéria-prima lítica. Neste sentido, ao invés de simplesmente descartar tanto no próprio sítio quanto em laboratório os vestígios brutos, é importante atentar para aspectos como matéria-prima, dimensões, grau de preservação, presença/ intensidade de alterações de superfície, tipo de suporte e, principalmente, localização.

No que se refere aos estudos de tecnologia lítica de maneira geral, um dos principais aspectos que pode ser aprofundado com a continuidade dos trabalhos com o material lítico do sítio Domingos envolve a realização de experimentações com matérias-primas dessa região a serem utilizadas em atividades possivelmente associadas às marcas de uso identificadas, quer dizer, atividades de processamento de vegetais. Isso poderia ser realizado por alunos e estagiários do Museu Emílio Goeldi e certamente traria uma grande contribuição não só para um melhor entendimento do sítio Domingos como também para os estudos de tecnologia lítica em geral. Este é, aliás, um ponto para o qual convergem as indústrias líticas de sítios cerâmicos e as indústrias líticas sambaquieiras, ambas ainda muito pouco estudadas e compreendidas no âmbito da Arqueologia Brasileira.

Além disso, a questão da utilização de certas matérias-primas líticas para produção de tempero mineral utilizado como antiplástico na produção cerâmica precisa ser investigada de forma mais detalhada e aponta para uma ampliação do leque de utilizações e atividades às quais o material lítico pode estar associado em ocupações ceramistas.

Outro ponto importante e que pode ser explorado envolve a produção de lâminas de machado com diferentes formas e segundo diferentes cadeias operatórias. No sítio Domingos há tanto lâminas de contorno trapezoidal, quanto lâminas retangulares e com orelhas e, ao mesmo tempo, há lâminas que foram feitas 
para serem utilizadas (as quais apresentam um acabamento menos refinado) e lâminas que não parecem ter sido confeccionadas para utilização (as quais estão fina e cuidadosamente polidas, sem nenhuma evidencia de uso).

Por fim, a relação entre técnicas de lascamento uni e bipolar há muito vem sendo debatida no âmbito da Arqueologia Brasileira embora pouco ainda se conheça efetivamente sobre o assunto (Prous 1986/90; Prous 2004; Prous e Lima 1986/90). Nesse sentido, efetuar uma descrição mais detalhada das cadeias operatórias presentes neste sítio no que se refere aos vestígios nos quais identificamos a associação de ambas as técnicas certamente viria a contribuir de modo significativo para as discussões relacionadas à tecnologia lítica.
Esse último ponto pode ainda ser realçado se pensarmos na especificidade da utilização dessa técnica no contexto da serra dos Carajás, uma vez que a indústria lítica encontrada nos abrigos da serra dos Carajás e associada a contextos de ocupação de caçadores-coletores que remontam a mais de 9.000 AP é caracterizada justamente pelo lascamento uni e bipolar de cristais de quartzo (Hilbert 1989; Magalhães 1994), os quais aparecem também no sítio Domingos, embora em baixa freqüência. Nesse sentido, estudar essa técnica de apropriação em relação com as matérias-primas nas quais ela é utilizada é uma questão bastante importante e que pode contribuir de maneira significativa no entendimento do processo de ocupação de longa duração dessa região.

BUENO, L.; PEREIRA, E. Lithic assemblages in Amazonian ceramic sites: a case study of Domingos site, Canaã dos Carajás, Pará. Revista do Museu de Arqueologia e Etnologia, São Paulo, 17: 99-126, 2007.

Abstract: This paper presents the results of the study of a lithic assemblage collected during the archaeological excavations realized by the "Programa de Arqueologia Preventiva na Área de Mineração Serra do Sossego". The lithic analysis focused the collection formed during the excavations of the Domingos site. These excavations happened in different periods from 2003 to 2005. The objectives of this analysis involved the identification of raw materials, the characterization of each process of appropriation, the definition of indexes of activity areas by the characterization of the type of modifications produced in the artifacts and the spatial distribution of the remains in the stratigraphy to investigate the existence of more than one occupation of the Domingos site. From the results of the technological analysis and the distribution of the lithic remains intra-site, we present a hypothesis on the site formation processes and show the great potential of the study of lithic technology in ceramist contexts.

Keywords: Lithic technology - Ceramic site - Activity area - Site formation processes.

\section{Referências bibliográficas}

AHLER, S. A.

1989 Mass analysis of flaking debris: studying the forest rather than the tree. In: Henry,
D.; Odell, G. (Eds.) Alternative Approaches to lithic analysis. Boulder Colorado : Westview Press. Archaeological Papers of 
the American Anthropological Association, 1: $85-118$

ANDREFSKY, W.

1998 Lithics: macroscopic approaches to analysis. Cambridge Manuals in Archaeology, Cambridge University Press.

2001 Lithic Debitage. Context, Form and Meaning. Utah: The University of Utah Press.

BRANDT/ MEIO AMBIENTE

2000 Estudo de Impacto Ambeintal da Mineração Serra do Sossego S.A. Canaã dos Carajás e Parauapebas, PA. CD-ROM Maio.

BUENO, L.R.

2007 Variabilidade tecnológica nas Indústrias Líticas da região do Lajeado, Médio Rio Tocantins. Revista do Museu de Arqueologia e Etnologia da USP, Suplemento 4, São Paulo.

2006 Indústrias Líticas do sul do Pará. Proposta de Análise para sítios associados a ocupações ceramistas e de caçadorescoletores. Relatório Final de Bolsa PCI, Museu Paraense Emílio Goeldi, julho.

COLliNS, M.B.

1975 Lithic Technology as a means of Processual Inference. In: Swanson, E. (Ed.) Lithic Technology. Making and Using Stone Tools. The Hauge-Paris, Mouton Publishers: 15-34.

COSTA, F.W.S.

2002 Análise das Indústrias líticas da área de confluência dos rios Negro e Solimões. Dissertação de Mestrado FFLCH/MAE, USP.

DIAS, A. S.; HOELTZ, S.

1997 Proposta metodológica para o estudo das indústrias líticas do sul do Brasil. Revista do CEPA, Santa Cruz do Sul, 21 (25): 21-62,

HILBERT, K.

1989 Organização e uso do espaço de grupos caçadores-coletores pré-históricos na gruta do gavião, serra dos Carajás (PA). Pontifícia Universidade Católica do Rio Grande do Sul.

LUIZ, J.G.; PEREIRA, E.

2005 Prospecção arqueológica por métodos geofísicos no sudeste do Pará: o caso do Sítio Domingos. Canaã dos Carajás. In: $9^{\text {th }}$ International Congress of the Brazilian Geophysical Society, Salvador. Explore new ideas in a mystical place, 1: 1-6. Cd-rom.

PEREIRA, E.

2005 Programa de Arqueologia preventiva na área da Mineração Serra do Sossego. Relatório de campo e de laboratório (etapa de maio, julho e outubro de 2003). Versão revista e ampliada. 162.p. inédito

2006a Programa de Arqueologia Preventiva na área da Mineração Serra do Sossego/PA. Relatório de campo (etapa de junho/ 2004). 118p. inédito.

2006b Programa de Arqueologia Preventiva na área da Mineração Serra do Sossego/PA. Relatório de campo e laboratório (etapa de setembro/2004). 109p. inédito

2006c Programa de Arqueologia Preventiva na área da mineração Serra do Sossego/PA. relatório de campo e laboratório (etapa de julho/agosto 2005). 210p. inédito

PRENTISS, W.C.

1998 The reliability and validity of a lithic debitage tipology: implications for archaeological interpretation. American Antiquity, 63 (4): 635-650.

PROUS, A.

1986/90 Os artefatos líticos, elementos descritivos classificatórios. Arquivos do Museu de História Natural, 11:1-55.

2004 Apuntes para el estudo de las industrias líticas.Ortegalia 02, Ortigueira.

PROUS, A.; LIMA, M.A.

1986/90 A tecnologia de debitagem do quartzo no centro de Minas Gerais: lascamento bipolar. Arquivos do Museu de História Natural, Belo Horizonte: Universidade Federal, 11: 91-111.

SHOTT, M.

1994 Size and Form in the analysis of flake debris: review and recent approaches. Journal of Archaeological Method and Theory, 1 (1): 69-110. 